\title{
Experimental Evidence on the Drivers of Index-Based Livestock Insurance Demand in Southern Ethiopia
}

\author{
KAZUSHI TAKAHASHI ${ }^{\mathrm{a}}$, MUNENOBU IKEGAMI ${ }^{\mathrm{b}}$, MEGAN SHEAHAN $^{\mathrm{c}}$ and \\ CHRISTOPHER B. BARRETT ${ }^{\mathrm{c}, *}$

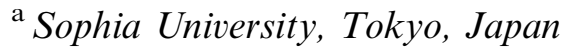 \\ ${ }^{\mathrm{b}}$ International Livestock Research Institute (ILRI), Nairobi, Kenya \\ ${ }^{\mathrm{c}}$ Cornell University, Ithaca, NY, USA
}

\begin{abstract}
Summary. - While index-based microinsurance has attracted considerable attention, uptake rates have been weak in many low-income countries. We explore the purchase patterns of index-based livestock insurance in southern Ethiopia, focusing on the role of accurate product comprehension and price. We find that randomly distributed learning kits improve subjects' knowledge of the products; however, we do not find strong evidence that the improved knowledge per se causes greater insurance uptake. We also find that reduced price due to randomly distributed discount coupons has an immediate, positive impact on uptake, without dampening subsequent period demand due to reference-dependence associated with price anchoring effects.

(c) 2015 Elsevier Ltd. All rights reserved.
\end{abstract}

Key words - index-based livestock insurance, experiment, uptake, Ethiopia

\section{INTRODUCTION}

Climate risks, such as drought, flood, typhoon, and increased variability in weather conditions between seasons, threaten many rural households' livelihoods in developing countries and are widely expected to grow more frequent with climate change (Carter, Little, Mogues, \& Negatu, 2007). Access to formal insurance services may help build resilience to these risks and protect households' longer run welfare in the event of climate shocks. Formal insurance, however, has remained underdeveloped in most poor, rural regions due to classic incentive problems associated with asymmetric information, such as moral hazard and adverse selection, as well as the high transaction costs involved in preventing opportunistic behavior by insurees. Available self-insurance options, both ex ante risk mitigation and ex post risk coping, are often costly, jeopardizing long-term household welfare (Morduch, 1995; Rosenzweig \& Wolpin, 1993). Given limited and inadequate self-insurance options, vulnerable rural households have developed mutual assistance mechanisms within their communities, which can partly, albeit not fully, help recover from losses due to idiosyncratic shocks (Bhattamishra \& Barrett, 2010; Dercon \& Krishnan, 2000; di Falco \& Bulte, 2013; Townsend, 1994; Udry, 1994). It is, however, well known that such informal risk sharing mechanisms do not function effectively under covariate, catastrophic natural disasters, where all neighboring community members suffer substantial losses (Barrett, 2011).

As a result, microinsurance - small-scale insurance products aimed at low-income people who are generally excluded from more traditional insurance markets - has attracted widespread interest as a means to enhancing the resilience of the rural poor against covariate climate risks (Churchill, 2006; de Bock \& Gelade, 2012). In particular, recently introduced index-based insurance has elicited considerable attention, especially since it is free from information asymmetry problems (Barnett, Barrett, \& Skees, 2008). Index insurance indemnity payouts are determined based not on actual losses experienced by policy holders, but on easily observable, objective weather or environmental parameters - such as rainfall, temperature, or remotely sensed estimates of vegetation levels - that are highly correlated with losses (Barnett et al., 2008; Zant, 2008). This allows insurers to avoid both the moral hazard and adverse selection problems associated with indemnification of losses specific to the insured as well as the significant transaction costs associated with monitoring the behavior and verifying the losses of the insured. While basis risk (i.e., the discrepancy between realized loss and indemnity payouts predicted by the index) remains a potential threat to policy holders (Jensen, Barrett, \& Mude, 2014; Jensen, Mude, \& Barrett, 2014; Miranda \& Farrin, 2012), index products offer at least partial insurance against otherwise-uninsured climate risks. Index-based weather insurance has therefore excited

\footnotetext{
*We are indebted to Eddy Chebelyon, Wako Gobu, Nathaniel Jensen, Mohamed Shibia, and Birhanu Taddesse for their excellent field assistance as well as Philemon Chelanga, Anne Gesare, Samuel Mburu, and Oscar Naibei for their careful data management. We thank Nicole Mason, Tomoya Matsumoto, Yasuyuki Sawada, editor Arun Agrawal, three anonymous referees, and seminar participants at GRIPS and Japan Economic Association for their helpful comments. This work was made possible by financial support provided by Cornell University, the International Livestock Research Institute (ILRI), the Institute of Developing Economies- Japan External Trade Organization (IDEJETRO), JSPS Grant-in-Aid for Scientific Research (B)- 26301021, the US Agency for International Development (USAID) Agreement No. LAG---A---00---96---90016---00 through Broadening Access and Strengthening Input Market Systems Collaborative Research Support Program (BASIS AMA CRSP), the Department of Foreign Affairs and Trade through the Australia Development Research Awards Scheme under an award titled "The human and environmental impacts of migratory pastoralism in arid and semi-arid East Africa", and CGIAR Research Programs on Climate Change, Agriculture and Food Security (CCAFS) and Dryland Systems. An earlier version of this article was circulated as the IDE discussion paper No. 480. All views and interpretations expressed in this publication are those of the authors and not necessarily those of the supporting or cooperating institutions. Final revision accepted: October 3, 2015.
} 
considerable interest as a prospective remedy for hithertounmet demand for mitigating covariate weather risks in rural areas of developing countries.

Despite sweeping claims that index-based microinsurance would be the next "revolution" in development practice (Morduch, 2006), the empirical evidence to date shows that unexpectedly low uptake, rarely above $30 \%$ of the intended population, causing many to rethink the attractiveness of the product or to suggest ways to improve it (de Bock \& Gelade, 2012; Leblois, Quirion, Alhassane, \& Traoré, 2014; Matul, Dalal, de Bock, \& Gelade, 2013; Miranda \& Farrin, 2012). This paper aims to contribute to the growing literature on index insurance uptake using the experience of a new index-based livestock insurance (IBLI) product introduced in pastoral southern Ethiopia in 2012. Most existing studies of index insurance uptake are rooted in the experience of crop insurance programs that insure against income loss from yield fluctuations; however, analysis of demand for index-based asset insurance, such as livestock insurance, remains scarce (Chantarat, Mude, Barrett, \& Carter, 2013; McPeak, Chantarat, \& Mude, 2010). To the extent that the livelihood systems, risk mitigation strategies, and the long-term welfare outcomes associated with shocks differ between crop-based and pastoral-based production systems, we would expect the demand for and benefits of index-based insurance to similarly diverge in these contexts. Although it is theoretically ambiguous whether crop or livestock insurance exhibits greater basis risk and loss adjustment costs, demand for IBLI could potentially exceed that for index-based crop insurance in that pastoralist households can protect not only temporary income, but also permanent income by purchasing insurance against livestock mortality from catastrophic drought (Chantarat et al., 2013; McPeak, 2004).

We use two waves of panel data, a baseline and a follow-up round between which respondent households had two (semiannual) opportunities to purchase an IBLI policy. Over the course of each IBLI sales period, we introduced two kinds of randomized experiments aimed at improving pastoralists' understanding of IBLI (via "learning kits" featuring comics and audio tapes of skits made by local performers) and their ability to pay (via discount coupons). These experimental interventions were intended to create incentives for IBLI uptake as the existing literature often identified them as important factors correlated with demand (Biener, 2013; Cai, de Janvry, \& Sadoulet, 2015; Cole et al., 2013; Gaurav, Cole, \& Tobacman, 2011; Giné, Townsend, \& Vickery, 2008; Karlan, Osei, Osei-Akoto, \& Udry, 2014; McIntosh, Sarris, \& Papadopoulos, 2013; Skees, 2008).

Our data reveal that uptake of IBLI approached $30 \%$ in the initial year of product offer, meeting or exceeding that of most other index-based insurance products in their pilot periods. Estimation results indicate that the reduced price of the insurance through the provision of discount coupons significantly increases the uptake of IBLI. While there is a potential threat that a one-time price reduction creates a price reference point that decreases demand in subsequent periods (Dupas, 2014; Fischer, McConnell, Karlan, \& Raffler, 2014), we find no evidence of such price anchoring effects. On the other hand, while the learning kits do boost accurate knowledge of the product, better knowledge does not appear to consistently increase uptake of IBLI.

The remainder of this paper is structured as follows. Section 2 explains the study site, sampling framework, and detailed designs of the IBLI product and experiments. Section 3 discusses descriptive statistics. Section 4 explains our estimation strategy, followed by discussion of results in Section 5. Section 6 concludes.

\section{DATA}

\section{(a) Study area}

Our study area is located on the Borana plateau in Oromia regional state of southern Ethiopia, covering the following eight woredas: Dilo, Teltele, Yabello, Dire, Arero, Dhas, Miyo, and Moyale. ${ }^{1}$ The Borana plateau covers around $95,000 \mathrm{~km}^{2}$, and the region is comprised of arid and semiarid ecological zones with four seasons: a long rainy season (March-May), a long dry season (June-September), a short rainy season (October-November), and a short dry season (December-February). Most of the population is pastoralist, whose livelihoods depend primarily on livestock. Herd migration in search of forage and water during the two dry seasons is common among pastoralists in this area.

The sustainability of pastoralism as a livelihood in Borana has been, however, significantly undermined due to recurrent drought, violent conflicts, and other political and economic instability (Desta, Berhanu, Gebru, \& Amosha, 2008; Tache, 2008). Among these, drought is by far the greatest cause of livestock mortality in our study area (Barrett \& Santos, 2014; Lybbert, Barrett, Desta, \& Coppock, 2004). Major droughts occurred almost every six or seven years between the mid-1970s and 2012 (i.e., 1973-74, 1983-84, 1991-92, 1999-2000, 2005-06, and 2011-12), each causing massive numbers of livestock deaths (Desta et al., 2008; Megeresa, Markemann, Angassa, \& Zárate, 2013). There exists a range of customary insurance arrangements that provide informal inter-household transfers in the form of cash or livestock. Yet many times the livelihoods of the entire community are threatened during drought, rendering traditional risk sharing arrangements weak and insufficient. Moreover these informal arrangements tend to cover only a small portion of household losses, usually exclude the persistently poor who need insurance the most, and are generally perceived to be in decline (Huysentruyt, Barrett, \& McPeak, 2009; Lybbert et al., 2004; Santos \& Barrett, 2011). In this setting, the demand for insurance that protects the pastoral population against drought-induced livestock losses should, therefore, be relatively substantial.

\section{(b) Design of IBLI}

To help pastoralists manage the considerable droughtrelated mortality risk, IBLI was introduced by the International Livestock Research Institute (ILRI) and Cornell University in collaboration with the Oromia Insurance Company (OIC) in August 2012 in the eight woredas listed above. The basic product design is similar to a previously designed IBLI product in northern Kenya that was rolled out in January 2010. As in northern Kenya, the standardized Normalized Differenced Vegetation Index (NDVI), a numerical indicator of the degree of greenness based on remotely sensed data collected by satellites, accumulated over one rainy season and the following dry season was used to construct an index (Chantarat et al., 2013; Mude et al., 2012). This index was calibrated for high correlation with average livestock mortality from drought at the woreda level. Indemnity payouts are triggered when the index falls below the 15 th percentile of the historical index distribution during 1981-2012.

IBLI is marketed and sold during two periods per year, directly preceding each rainy season (August-September and January-February), with coverage lasting one year and the potential for two indemnity payouts, one after each dry season. During each sales period, a household decides whether 
to buy IBLI and, if so, how many animals to insure. A premium payment is equal to the calculated total insured herd value (TIHV) ${ }^{2}$ in Ethiopian birr $^{3}$ multiplied by a woredaspecific insurance premium rate given spatial differences in expected mortality risk. ${ }^{4}$ More precisely,

$$
\begin{aligned}
\text { TIHV }= & (\# \text { of camel insured }) * 15,000 \\
& +(\# \text { of cows insured }) * 5,000 \\
& +(\# \text { of goats and sheep insured }) * 700
\end{aligned}
$$

and

Premium payment $=$ Woreda-specific insurance premium rates

$$
\text { * TIHV. }
$$

If a household buys IBLI in the August-September sales period, it is insured from October 1 to September 30 of the following year and may receive indemnity payouts in March and/ or October of the year following purchase. Note that if a pastoral household buys IBLI not only in the August-September sales period but also the following January-February sales period, then insurance coverage periods for the two contracts overlap from March to September, and the household may receive indemnity payouts for both contracts in October. This seasonally overlapping design allows households to insure the same number of livestock but pay less on more frequent intervals and is, therefore, expected to reduce the cash constraints faced by pastoralists.

The feature of two potential payouts in a year and the 15 th percentile trigger level makes an expected probability of payout occurring once every three and a half years. The indemnity payouts, if triggered, will be equal to the premium payment at a minimum and to half of TIHV at a maximum, depending on the realized NDVI. Within the period of data we study in this paper, two sales periods occurred, the first in August-September 2012 and the second in January-February 2013, and no indemnity payouts were made to insured households.

\section{(c) Sampling framework}

While IBLI was marketed and sold to any household on the Borana plateau, we study a random sample of households across the eight woredas to explore the pattern of IBLI uptake among pastoralists. The baseline survey data were collected in March-April 2012 before the first IBLI sales period (AugustSeptember 2012) was announced, with a follow-up survey implemented in April 2013 directly after the second IBLI sales period (January-February 2013). Sampling for the household survey is clustered at the reera level, the smallest administrative unit after kebele, which consists of 100-300 households. Sample reeras (hereafter, called study sites) were selected so as to maximize agro-ecological and livelihood variation across the Borana pastoral area. Reeras inaccessible by vehicle were, however, excluded for logistical and cost reasons. Out of 387 total, 17 study sites were selected and, within these, development agents (DAs) who worked in the survey areas as local development officers completed a population and livestock holding census. Households in the census were then split into wealth terciles based on the number of livestock held. Then, $15 \%$ of households per study site were selected for the sample, one third from each of the livestock holding terciles, totaling 528 households across the 17 study sites. Due to logistical challenges in the March-May rainy season, however, baseline data were collected from only 515 of the selected sample in March 2012. This study draws on information from the 474 households that constitute a balanced panel (resurveyed in
April 2013) and contain complete data sets in both captured sales periods. 5

\section{(d) Experimental interventions}

To stimulate uptake of IBLI and construct an experimental research design, three different interventions were offered to randomly selected subpopulations during each of the two sales periods. The first component of the experiment was intended to increase overall awareness of IBLI and to improve knowledge of how the product worked and its potential benefits. This was done through the use of two tools referred to together as a "learning kit" - a comic and an audio tape of a skit - which were distributed randomly to households within randomly selected study sites through separate processes in each sales period. Study sites were stratified into three categories, i.e., those located closer to major livestock markets, those with sparse rainfall, and those located far from functioning livestock markets and within which households generally hold larger herds. Within each of these three strata, sites were randomly assigned comic and skit tape treatments, keeping at least one site as a control (no learning kit). Half of the households in each treatment site received the relevant learning kit and half did not.

The second component of the experiment was the distribution of discount coupons which lowered the cost of purchasing IBLI. With a coupon, the recipient could purchase IBLI at a discounted rate for the first 15 Tropical Livestock Units (TLUs) ${ }^{6}$ insured. In each study site and each sales period, households offered discount coupons were randomly chosen to receive coupons ranging from $10 \%$ to $80 \%$ in order to manufacture exogenous variation in the effective price faced by prospective IBLI purchasers. Twenty percent of the sample households did not receive a coupon during each sales period and in total $4.6 \%$ of the sample households did not receive a coupon during the both periods. ${ }^{7}$

To implement these experiments, DAs were trained to explain and distribute the coupons to the study households either in collective meetings or, less often, in separate personal visits. For the comic, DAs read and gave a paper version of the comic to treatment recipients, again either in community meetings or individually. Similarly, the DAs convened group meetings or met households at their home to play the audio tape of the skit describing IBLI. Unfortunately, ILRI staff found that some DAs did not implement these random assignments rigorously in the first sales period, especially for the cartoon and skit tape. Consultants were hired to implement these activities in the second sales period together with DAs to improve the quality of implementation. As a result, we use an intent-to-treat estimation strategy that will allow us to ignore imperfect compliance.

\section{SUMMARY STATISTICS}

Table 1 presents selected descriptive statistics derived from the baseline data collected in early 2012 for the full sample then separately for those households that did and did not purchase IBLI. We refer to the overall sample below to describe the general characteristics of households in our study, except for those several variables that are statistically significantly different between these two sets of households.

The average household size is 6.3 , with a male-female ratio close to one. The average age of household heads, which are predominantly male, is approximately 50 years. Ninety percent of household heads have never attended formal school, and therefore the average amount of completed 
Table 1. Baseline socio-economic characteristics of the sampled households (March 2012)

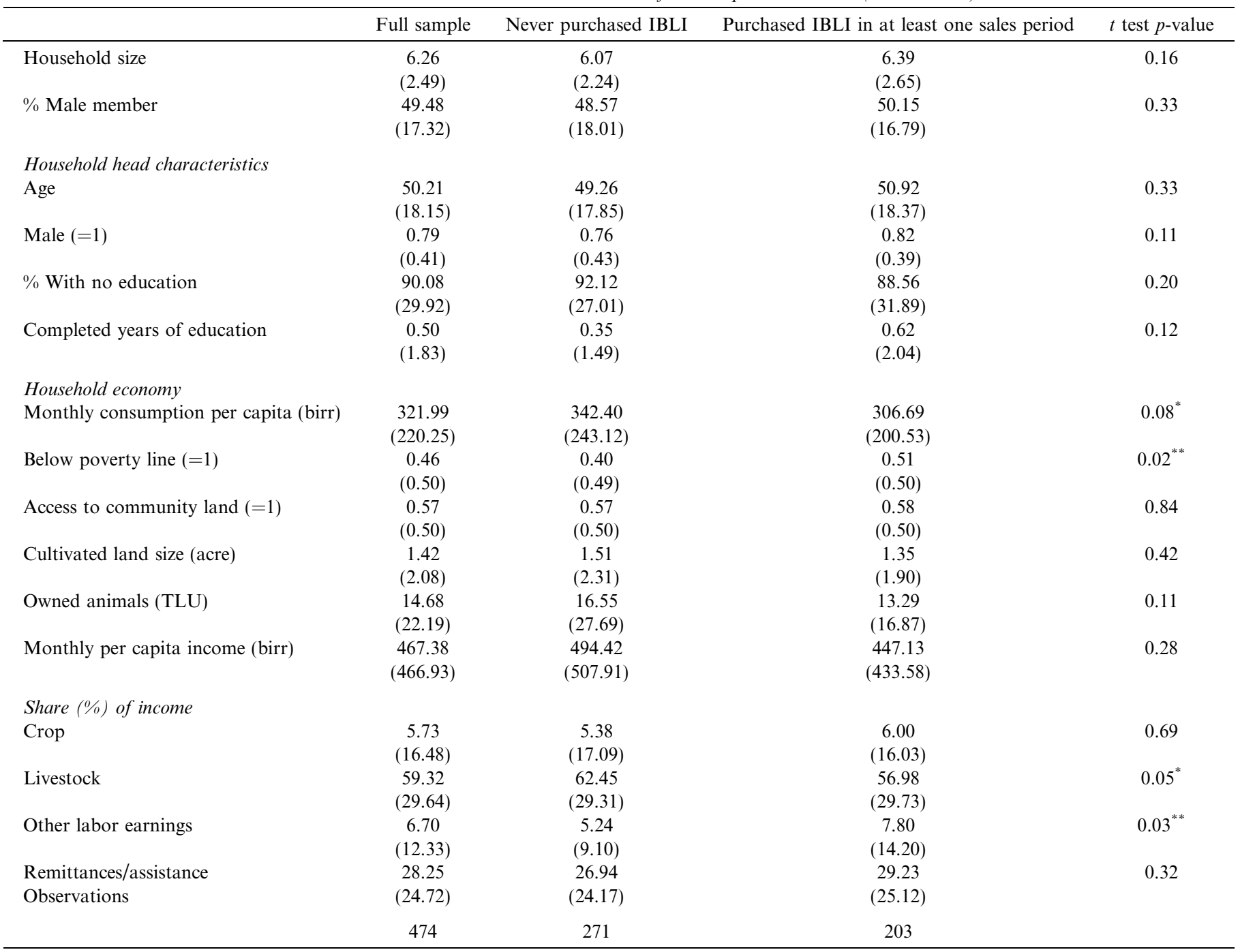

Note: Standard deviations are in parentheses. The $t$-test represents the difference in characteristics between households that have never purchased IBLI and those that have purchased in at least one sales period. ${ }^{* * *} p<0.01,{ }^{* *} p<0.05,{ }^{*} p<0.1$.

education is only half a year which is quite low even relative to an average of 4.7 years across all Ethiopian households (McIntosh et al., 2013).

The average monthly household consumption per capita is 322 birr, and $46 \%$ of the households fall below the $\$ 1.25$ (purchasing power parity) per day international poverty line. Those households that subsequently purchased IBLI tend to be wealthier than those that did not. As noted previously, the predominant source of income is livestock, including milk and meat production, which accounts for approximately $59 \%$ of total household income. Other income sources, such as crop production and off-farm activities, play a relatively minor role; only $15 \%$ of households derive income from crop production with the unconditional average share of crop income within the total household income to be only $6 \%$ and average cultivated land size of 1.4 acres. Livestock comprises the overwhelming majority of households' non-human assets. The average TLU of animal owned by sample households are 14.7, dominated by large cattle herds and supplemented with goats, sheep, and camels.
Table 2 shows the percent of sampled households that purchased IBLI in each sales period as well as the average animals insured, in terms of TLU and TIHV, separately for those who purchased IBLI in both periods, only the first period, only the second period, and never purchased. ${ }^{8}$ About $30 \%$ of sampled households purchased IBLI during the first period, which is comparable to or higher than most other index-based insurance products in their pilot periods (Cole et al., 2013; Giné et al., 2008), but that rate declined to $18 \%$ in the second period. Only 24 out of 474 households bought IBLI in both sales periods to generate overlapping coverage for the March-September 2013 period. The number of insured TLU is relatively small. The unconditional mean is only 0.79 at the first period and 0.50 in the second period, which represents less than $5 \%$ of all animals owned. The average TIHV is 4.2 thousand birr in the first sales period and 2.6 thousand birr at the second sales period, respectively, which are close to or only slightly greater than the average monthly household income. Those who purchased IBLI during both sales periods tend to 
Table 2. Patterns of IBLI purchase, 2012-13

\begin{tabular}{|c|c|c|c|c|c|}
\hline & Full sample & $\begin{array}{c}\text { Households } \\
\text { that purchased } \\
\text { IBLI in both } \\
\text { 1st and 2nd sales periods }\end{array}$ & $\begin{array}{l}\text { Households that } \\
\text { purchased } \\
\text { IBLI only } \\
\text { in 1st sales period }\end{array}$ & $\begin{array}{l}\text { Households that } \\
\text { purchased IBLI } \\
\text { only in } \\
\text { 2nd sales period }\end{array}$ & $\begin{array}{l}\text { Households that } \\
\text { never purchased } \\
\text { IBLI }\end{array}$ \\
\hline \multicolumn{6}{|l|}{ 1st sales period (August 2012) } \\
\hline \multirow[t]{2}{*}{$\%$ Household buy IBLI } & 29.54 & 100.00 & 100.00 & - & - \\
\hline & $(45.67)$ & $(0.00)$ & $(0.00)$ & - & - \\
\hline \multirow[t]{2}{*}{ Insured TLU, including zeros } & 0.79 & 4.43 & 2.33 & - & - \\
\hline & $(2.41)$ & $(5.40)$ & $(3.33)$ & - & - \\
\hline \multirow[t]{2}{*}{ Insured TLU, conditional on purchase } & 2.69 & 4.43 & 2.33 & - & - \\
\hline & $(3.82)$ & $(5.40)$ & $(3.33)$ & - & - \\
\hline \multirow[t]{2}{*}{ Insured TIHV (in 1,000 birr, including zeros } & 4.15 & 23.24 & 12.16 & - & - \\
\hline & $(12.28)$ & $(27.49)$ & $(16.67)$ & - & - \\
\hline \multirow{2}{*}{$\begin{array}{l}\text { Insured TIHV (in 1,000 birr). conditional } \\
\text { on purchase }\end{array}$} & 14.06 & 23.24 & 12.16 & - & - \\
\hline & $(19.30)$ & $(27.49)$ & $(16.67)$ & - & - \\
\hline \multicolumn{6}{|l|}{ 2nd sales period (February 2013) } \\
\hline \multirow[t]{2}{*}{$\%$ Household buy IBLI } & 18.35 & 100.00 & - & 100.00 & - \\
\hline & $(38.75)$ & $(0.00)$ & - & $(0.00)$ & - \\
\hline \multirow[t]{2}{*}{ Insured TLU, including zeros } & 0.50 & 5.13 & - & 1.83 & - \\
\hline & $(2.10)$ & $(6.03)$ & - & $(2.92)$ & - \\
\hline \multirow[t]{2}{*}{ Insured TLU, conditional on purchase } & 2.74 & 5.13 & - & 1.83 & - \\
\hline & $(4.25)$ & $(6.03)$ & - & $(2.92)$ & - \\
\hline \multirow[t]{2}{*}{ Insured TIHV (in 1,000 birr), including zeros } & 2.64 & 25.85 & - & 10.01 & - \\
\hline & $(10.81)$ & $(30.05)$ & - & $(15.81)$ & - \\
\hline \multirow{2}{*}{$\begin{array}{l}\text { Insured TIHV (in 1,000 birr), conditional } \\
\text { on purchase }\end{array}$} & 14.38 & 25.85 & - & 10.01 & - \\
\hline & $(21.73)$ & $(30.05)$ & - & $(15.81)$ & - \\
\hline Observations & 474 & 24 & 116 & 63 & 271 \\
\hline
\end{tabular}

Note: Average values of insurance are included in the table. Standard deviations are in parentheses.

Table 3. Most important reported reasons for non-purchase of IBLI, 2012-13

\begin{tabular}{|c|c|c|c|c|}
\hline & \multicolumn{2}{|l|}{$\begin{array}{c}\text { 1st sales period } \\
\text { Aug } 2012\end{array}$} & \multicolumn{2}{|l|}{$\begin{array}{c}\text { 2nd sales period } \\
\text { Feb } 2013\end{array}$} \\
\hline & Number of observations & $\%$ & Number of observations & $\%$ \\
\hline Do not have money to spend on insurance & 71 & 24.7 & 99 & 31.5 \\
\hline Did not understand insurance well enough to buy it & 100 & 34.7 & 49 & 15.6 \\
\hline Did not have an opportunity to buy it & 50 & 17.4 & 65 & 20.7 \\
\hline Do not have enough animals & 41 & 14.2 & 57 & 18.2 \\
\hline Waiting to see what happens to the people who bought insurance & 11 & 3.8 & 20 & 6.4 \\
\hline Do not think insurance will help me & 7 & 2.4 & 7 & 2.2 \\
\hline Afraid of uncertainty in insurance & 2 & 0.7 & 9 & 2.9 \\
\hline Do not trust any insurance companies & 3 & 1.0 & 3 & 1.0 \\
\hline Can rely on family and friends & 2 & 0.7 & 4 & 1.3 \\
\hline Discouraged by someone in the community & 1 & 0.4 & 1 & 0.3 \\
\hline Total & 288 & 100 & 314 & 100 \\
\hline
\end{tabular}

insure more animals than those who purchased it in either the first or second period only.

Table 3 displays the main reason the 2013 survey respondents gave for not purchasing IBLI. The top two reasons are the lack of cash followed by the lack of knowledge about IBLI, mimicking the major constraints commonly raised across other index-based insurance pilots in the developing world (Cai et al., 2015; Cole et al., 2013; Gaurav et al., 2011; Giné et al., 2008; Karlan et al., 2014) despite the fact that our discount coupons aimed to partly mitigate the liquidity constraints via reducing the cost of insurance and our learning kits aimed to improve understanding of IBLI.

To obtain deeper insight into the effectiveness of our experimental interventions, we examined the sources of information for those respondents who had heard about IBLI using the 2013 data. DAs and ILRI staff were the most significant information channels, with $86 \%$ and $67 \%$ of respondents citing them as IBLI information sources respectively. Meanwhile, a non-negligible number of households claimed to obtain information about IBLI through the experimental interventions, although some treated respondents did not recognize these as an IBLI information source.

In the 2013 survey, we also implemented an eight question quiz about IBLI, including questions about the insurer, the conditions, frequency, and amount of indemnity payout in addition to simple computations of premiums and payouts under hypothetical scenarios. A $t$-test reveals that the mean number of correct answers (not shown in table) is statistically 


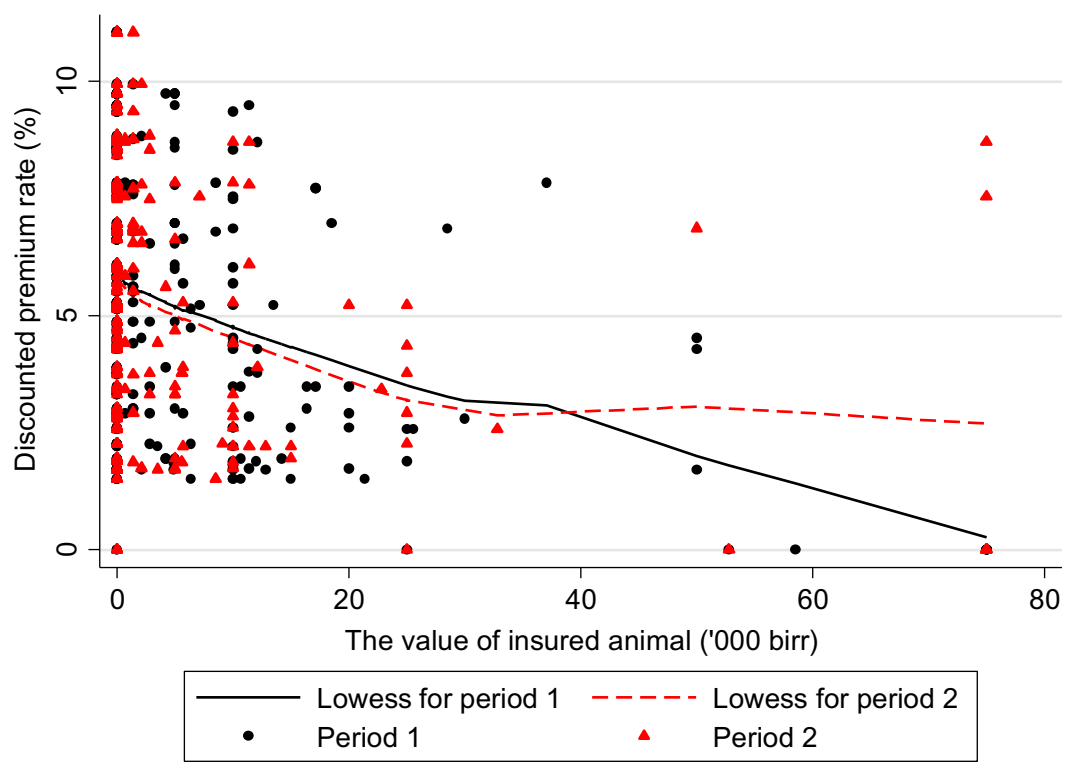

Figure 1. IBLI demand curve. Note: The vertical axis measures the discounted premium rate (\%), defined as the woreda-specific premium rate multiplied by one minus the household-specific discount rate. The horizontal axis measures the total value of insured animals, where each camel, cattle, and goat/sheep is equivalent to 15, 5, and 0.7 thousand birr, respectively. Solid and dashed lines represent the lowess smoothing curves for the first and second sales period, respectively. $(n=474)$.

significantly larger among respondents who received the learning kit treatments, either a comic or a skit, during the second sales period, when the experimental implementation was more closely supervised and done correctly. We do not find any significant difference at the first sales period.

Figure 1 displays the relationship between TIHV and a household-specific premium rate, where a household-specific premium rate is defined as ${ }^{9}$ :

\section{Household specific premium rate}

$$
=(1 \text {-discount rate }) * \text { Woreda specific premium rate } .
$$

As expected, the IBLI uptake decreases with the householdspecific premium rates, suggesting that IBLI demand is price responsive and that discount coupons may induce uptake. Descriptively, our experiments seem to have contributed to spreading information about the existence of IBLI as well as to inducing uptake in the study sites.

\section{ESTIMATION STRATEGY}

In order to more rigorously study IBLI uptake we turn to multivariate regression analysis. We are interested not only in whether or not households choose to buy IBLI in a given sales period, but also how many animals they choose to insure, measured by TIHV, conditional on purchasing an IBLI policy. Since more than half of all households do not buy IBLI at all, parameters estimated via Ordinary Least Squares (OLS) would be biased and inconsistent. One standard approach to consistently estimating a model with a continuous dependent variable with censored observations is the standard Tobit model. The standard Tobit (i.e., Type I Tobit), however, imposes a rather restrictive assumption that the decision to buy IBLI and decisions about how many TLU to insure are determined by a single process, which need not be true. ${ }^{10}$

To overcome the restrictive assumptions inherent in the standard Tobit model, we employ the "double-hurdle" (DH) model originally proposed by Cragg (1971). The DH model is more flexible than the standard Tobit in that it assumes the observed demand for IBLI can be decided in a step-wise manner, i.e., first the decision whether or not to buy IBLI, followed by the second decision on the quantity of animals to insure. The underlying decision-making process of the $\mathrm{DH}$ model can be expressed as:

$d_{i t}= \begin{cases}1 & \text { if } d_{i t}^{*}=m_{i t} \alpha_{t}+\xi_{i t}>0 \\ 0 & \text { otherwise }\end{cases}$

$y_{i t}= \begin{cases}y_{i t}^{*} & \text { if } y_{i t}^{*}=X_{i t} \beta_{t}+\varepsilon_{i t}>0 \quad \text { and } \quad d_{i t}^{*}>0 \\ 0 & \text { otherwise }\end{cases}$

where $d_{i t}$ is a binary indicator variable to describe whether household $i$ bought IBLI during sales period $t, y$ represents TIHV, $d^{*}$ and $y^{*}$ are the unobserved latent variables, $m$ and $X$ are vectors of explanatory variables, and $\alpha$ and $\beta$ are estimated parameters. Because we observe two separate sales periods, this model can be run separately for each period.

Following Cragg (1971), we assume that the first-hurdle error term $\xi_{i t}$ and second-hurdle error tem $\varepsilon_{i t}$ (e.g., error terms in Eqns. (1) and (2)) are independently and normally distributed with zero mean at each sales period, conditional on observed covariates. While covariance between those errors can be non-zero, Garcia and Labeaga (1996) and Jones (1992), among others, show that estimated results are often quite similar regardless of whether the assumption of zero covariance is relaxed. Given that we do not have exclusion restrictions for identifying the effect of the participation decision, independent of the purchase volume choice, we maintain the assumption of zero covariance between the first- and second-hurdle error terms. ${ }^{11}$ Given conditionally independent error terms, the log likelihood function for the DH model can be equivalent to the sum of the log-likelihoods of a probit model and truncated regression model (Burke, 2009; Cragg, 1971). Thus, separate regressions for the first hurdle with the probit, followed by the second hurdle with the truncated regression, yield consistent estimates with the $\mathrm{DH}$ model described above (Ricker-Gilbert, Jayne, \& Chirwa, 2011). 
Major explanatory variables of interest in the first- and second sales period DH models include the effective price of IBLI faced by each household and the knowledge of IBLI. The former is captured by the inclusion of household- and sales period-specific premium rates as well as a dummy variable to represent which households received a discount coupon. As shown in Table 7, we found a significant difference between the administrative records on discount coupon disbursement and households' self-reported receipt of coupons. Since the administrative records precisely capture the results of random assignment, we prefer to include them over self-reports. If there is any noncompliance in distributing those coupons, as implied in the first sales period given reports to ILRI, our estimates will reflect "intention to treat" effects.

Knowledge of IBLI is proxied using the number of correct answers to the quiz about IBLI administered during data collection. The data are derived only from the second wave of the survey because we did not ask the knowledge of IBLI at the time of baseline survey, as the product had not yet been designed or marketed. An obvious concern is that households with greater interest in IBLI know more about the product and are more likely to buy, or that knowledge of IBLI increases after a household bought IBLI, causing an endogeneity problem. To address this, we apply a two-step estimation strategy, where we first estimate the number of correct answers to the quiz, and then estimate the DH models including the predicted number of correct answers from the first stage as one of the regressors. The intent to treat dummies of skit tapes and comics, ${ }^{12}$ which are purely exogenous by experimental design, are used as instruments to identify the exogenous component of knowledge of IBLI but are excluded from the demand model under the assumption that the learning kits should only influence uptake through an increase in knowledge.

Other controls are constructed from the baseline survey to minimize potential endogeneity concerns and to provide an ex ante picture of the household before IBLI was introduced (see Table 8 for a full list of explanatory variables). These include: (1) monthly per capita household income and the proportion of household income from livestock; (2) household livestock holdings, measured in TLU, and a squared term to allow for nonlinear effects; (3) the value of non-livestock assets, represented by a wealth index computed using principal component analysis following the Sahn and Stifel (2000) method; (4) the amount of cultivated land; (5) characteristics of the household and household head, such as household size and age, years of completed education, and gender of household head; (6) the household's subjective expected livestock mortality within the year following the baseline survey; (7) dummy variables that capture whether households expect livestock prices to increase or to remain the same within a year from the baseline survey; (8) risk tolerance dummies elicited through field experiments following Binswanger (1980) ${ }^{13}$; and (9) woreda dummy variables, which function as controls for the woreda-level unobservables. Standard errors are clustered at the study site level for all regressions. ${ }^{14}$

\section{ESTIMATION RESULTS}

\section{(a) Static estimation}

Table 4 presents the estimated results of the first step regression for factors associated with the knowledge of IBLI. The first sales period coupon recipients tend to have better knowledge about IBLI. The second sales period random "learning kit" assignments are positively correlated with the number of correct answers, while the first sales period assignments are not, which might be because some DAs did not implement these random assignments correctly during the first sales period, as explained earlier. This raises a concern that we do not have valid instruments for the knowledge of IBLI during the first sales period, although it will not call into question the second round results. To examine whether the results stand up to a robustness check, we also refer to estimates using the number of correct quiz answers in the first sales period. Other important determinants of IBLI knowledge include education of the household head, which has the positive impacts.

The main DH estimation results, incorporating instrumented values of the number of correct quiz answers from the first step regression above, are presented in Table 5, where the dependent variable of probit regressions (i.e., columns (1), and (3)) takes one if the household bought IBLI during that sales period, while the dependent variable of the truncated regressions (i.e., columns (2) and (4)) represents TIHV measured in thousand birr. The predicted number of correct answers to the quiz is negatively correlated with the probability of purchase IBLI in the first sales period, but positively related to the probability of uptake in the second period, and statistically insignificantly related to TIHV in the first and second sales periods. Note that naïve estimation with the number of correct quiz answers based on the actual (not predicted) value, a clearly endogenous variable, generates an opposing sign for the probability of uptake in the first sales period (Panel A of Table 10), which may reflect that those wishing to buy IBLI make an effort to learn more about it. This signals that we have a weak instrument in the first period uptake equation due to the imperfect implementation of the experimental design in the first sales period. As a result, the relationship between IBLI knowledge and uptake is unclear in the first sales period. But in the second sales period, when the experiment was properly implemented, the instrument is strong and the expected, positive causal effect of improved knowledge on uptake is apparent.

Household demand for IBLI is clearly sensitive to the price the household faces. In each sales period, the household-andround-specific premium rates consistently and negatively affect the decision to purchase as well as the value of animals insured. The estimated marginal impacts ${ }^{15}$ of the premium rates are -1.65 and -1.22 at the first and second sales periods, respectively, implying that that a decrease in the premium rate by one percentage point is associated with increases in the value of animal insured by 1.65 and 1.22 thousand birr at the first and second sales periods, respectively. After controlling for price, IBLI demand is not significantly and consistently affected by whether households receive a coupon or not, except for the decision to buy IBLI in the first sales period, during which coupon recipients were more likely to purchase IBLI. ${ }^{16}$

Note that the discounted premium rates may have income effects aside from the pure price effect. Although we expect such income effects are small in our context, as the reduction in the premium rate is minor relative to the total household income, we cannot rule out that possibility. Indeed, the estimated results show that the increased household income tends to increase the total insured value of livestock.

The proportion of income from livestock is positively correlated with the probability of buying IBLI during the first sales period, reflecting that households with more diversified income portfolios are less likely to rely on IBLI as a riskcoping mechanism. This view is also partly supported by the coefficient estimates on cultivated land size, which tend to show the negative impacts, implying that those households with more crop income generating capacity are less likely to rely on IBLI. 
Table 4. First stage estimation results: IBLI knowledge

Dependent variable: The number of

correct answers to quiz

\begin{tabular}{|c|c|}
\hline Coupon in the 1st sales period $(=1)$ & $\begin{array}{c}0.628^{* * *} \\
(0.234)\end{array}$ \\
\hline Comic in the 1 st sales period $(=1)$ & $\begin{array}{c}0.281 \\
(0.240)\end{array}$ \\
\hline Skit in the 1 st sales period $(=1)$ & $\begin{array}{l}-0.333 \\
(0.268)\end{array}$ \\
\hline Coupon in the 2 nd sales period $(=1)$ & $\begin{array}{c}0.143 \\
(0.240)\end{array}$ \\
\hline Comic in the 2 nd sales period $(=1)$ & $\begin{array}{l}1.136^{* * *} \\
(0.233)\end{array}$ \\
\hline Skit in the 2 nd sales period $(=1)$ & $\begin{array}{l}0.580^{* *} \\
(0.244)\end{array}$ \\
\hline Per capita household income (in 1,000 birr) & $\begin{array}{l}-0.155 \\
(0.283)\end{array}$ \\
\hline TLU & $\begin{array}{c}0.007 \\
(0.010)\end{array}$ \\
\hline TLU squared & $\begin{array}{l}-0.000 \\
(0.000)\end{array}$ \\
\hline Proportion of income from livestock & $\begin{array}{c}0.001 \\
(0.003)\end{array}$ \\
\hline Cultivated land (acre) & $\begin{array}{c}0.001 \\
(0.054)\end{array}$ \\
\hline Wealth index & $\begin{array}{c}0.016 \\
(0.109)\end{array}$ \\
\hline HH size & $\begin{array}{l}-0.050 \\
(0.047)\end{array}$ \\
\hline Head age & $\begin{array}{c}0.001 \\
(0.031)\end{array}$ \\
\hline Head age squared & $\begin{array}{l}-0.000 \\
(0.000)\end{array}$ \\
\hline Head male $(=1)$ & $\begin{array}{c}0.388 \\
(0.238)\end{array}$ \\
\hline Head completed years of education & $\begin{array}{l}0.127^{* *} \\
(0.054)\end{array}$ \\
\hline Expected mortality rate & $\begin{array}{l}-0.002 \\
(0.003)\end{array}$ \\
\hline Expected livestock price (unchange) $(=1)^{\mathrm{a}}$ & $\begin{array}{l}-0.402 \\
(0.365)\end{array}$ \\
\hline Expected livestock price (higher) $(=1)^{\mathrm{a}}$ & $\begin{array}{c}0.191 \\
(0.215)\end{array}$ \\
\hline Moderate risk averse $(=1)^{\mathrm{b}}$ & $\begin{array}{c}0.027 \\
(0.224)\end{array}$ \\
\hline Less risk averse $(=1)^{\mathrm{b}}$ & $\begin{array}{l}-0.250 \\
(0.211)\end{array}$ \\
\hline Constant & $\begin{array}{l}3.952^{* * *} \\
(0.920)\end{array}$ \\
\hline Woreda dummy variables & YES \\
\hline Observations & 474 \\
\hline$R$-Squared & 0.188 \\
\hline $\begin{array}{l}\text { Joint } F \text {-test on comic and skit tape } \\
\text { dummies in both periods }\end{array}$ & $7.56^{* * *}$ \\
\hline $\begin{array}{l}\text { Joint } F \text {-test on comic and skit tape } \\
\text { dummies only in the } 2 \text { nd period }\end{array}$ & $12.78^{* * *}$ \\
\hline
\end{tabular}

Note: Heteroscedasticity robust clustered standard errors at the study-site level are in parentheses. ${ }^{* * *} p<0.01,{ }^{* *} p<0.05,{ }^{*} p<0.1$.

${ }^{a}$ The omitted category is that expected livestock price becomes lower.

${ }^{\mathrm{b}}$ The omitted category is extremely risk averse.

As Table 3 shows, "insufficient livestock holdings" is an important reason provided by households for not purchasing IBLI. However, through regression analysis, we find that total household TLU holdings largely do not affect the decision to purchase IBLI independent of the share of income earned from livestock. On the other hand, wealth index shows that wealthier people are more likely to insure more animals in both the first and second sales periods.

Other socio-economic characteristics of the household and household head are also associated with IBLI demand. First, male-headed households are more likely to buy larger insurance policies in the first sales period, although they are less likely to buy IBLI in the second sales period. Second, although we a priori expected the education of the household to be positively associated with IBLI demand, it is actually negatively correlated in three of four models, statistically significantly so for two of them. This is in sharp contrast to the existing literature that finds the positive role of education in uptake of microinsurance (Giesbert, Steiner, \& Bendig, 2011; Giné \& Yang, 2009; Jowett, 2003). We suspect that part of the impact of head's education is captured in the coefficient on predicted IBLI knowledge since the two are positively correlated in the first stage regression. Yet, dropping the IBLI knowledge variable does not alter the result. Those educated household heads may have superior access to alternative insurance or safety net mechanisms through social networks, jobs or relief agencies.

Households that expect livestock prices to remain constant or rise are more likely to buy IBLI and tend to insure greater animal value. On the other hand, risk preference dummies are largely negative, and statistically significant in some cases, suggesting that risk-averse households buy IBLI more. This is consistent with the conventional theory, although several existing studies on index insurance products show mixed results (e.g., Giné et al., 2008).

\section{(b) Dynamic estimation}

So far, we have implicitly assumed that the demand for IBLI is independent over time. Yet, it is possible that the second sales period choice is conditional on the first sales period decision, particularly since the two contracts' coverage periods overlap. Also, as information diffuses and people learn from their own and others' experiences, perceptions about and demand for IBLI may change over time. To account for such potential dynamic adoption behavior, we use a slightly modified version of the DH model. Instead of using the univariate probit model in the first hurdle at the second sales period, as in Eqn. (1), we apply an endogenous switching probit model where first sales period purchasers and non-purchasers of IBLI are separated into different regimes to decide whether to buy IBLI in the second sales period. This modifies the Eqns. (1) and (2) to:

$d_{i 1}= \begin{cases}1 & \text { if } d_{i 1}^{*}=m_{i 1} \alpha_{1}+\xi_{i 1}>0 \\ 0 & \text { otherwise }\end{cases}$
$d_{i 2}^{1}=\left\{\begin{array}{ll}1 & \text { if } d_{i 2}^{1 *}=m_{i 2} \alpha_{2}^{1}+u_{i 2}^{1}>0 \\ 0 & \text { otherwise }\end{array}\right.$ iff $m_{i 1} \alpha_{1}+\xi_{i 1}>0$

$d_{i 2}^{0}=\left\{\begin{array}{l}1 \text { if } d_{i 2}^{0 *}=m_{i 2} \alpha_{2}^{0}+u_{i 2}^{0}>0 \\ 0 \text { otherwise }\end{array}\right.$ iff $m_{i 1} \alpha_{1}+\xi_{i 1} \leqslant 0$

$y_{i 2}=\left\{\begin{array}{l}y_{i 2}^{*} \text { if } y_{i 2}^{*}=X_{i 2} \beta_{2}+\varepsilon_{i 2}>0 \text { and }\left(d_{i 2}^{0 *}>0 \text { or } d_{i 2}^{1 *}>0\right) \\ 0 \quad \text { otherwise }\end{array}\right.$

where $m_{i 1}$ is the vector of household characteristics during the first sales period; $\alpha_{1}$ is the coefficient of observed characteristics during the first sales period; $\xi_{i 1}$ is the error term during 
Table 5. Second stage estimation results on demand for IBLI (static double hurdle model)

\begin{tabular}{|c|c|c|c|c|}
\hline \multirow{2}{*}{$\begin{array}{l}\text { Sales period } \\
\text { Dependent variable }\end{array}$} & \multicolumn{2}{|c|}{1 st } & \multicolumn{2}{|r|}{ 2nd } \\
\hline & Dummy for IBLI purchase & Total insured herd value & $\begin{array}{c}\text { Dummy for IBLI } \\
\text { purchase }\end{array}$ & Total insured herd value \\
\hline Estimation model & Probit (1) & Truncated regression (2) & Probit (3) & Truncated regression (4) \\
\hline \# Correct answer on IBLI quiz: predicted & $\begin{array}{c}-0.292^{* *} \\
(0.141)\end{array}$ & $\begin{array}{l}-1.591 \\
(4.839)\end{array}$ & $\begin{array}{l}0.206^{*} \\
(0.118)\end{array}$ & $\begin{array}{c}6.811 \\
(5.794)\end{array}$ \\
\hline Period-specific coupon recipient $(=1)$ & $\begin{array}{l}0.460^{* *} \\
(0.205)\end{array}$ & $\begin{array}{l}-21.517 \\
(25.365)\end{array}$ & $\begin{array}{c}0.113 \\
(0.334)\end{array}$ & $\begin{array}{l}-35.702 \\
(64.720)\end{array}$ \\
\hline Household-period-specific premium rate & $\begin{array}{l}-0.125^{* * *} \\
(0.029)\end{array}$ & $\begin{array}{l}-15.583^{* * *} \\
(3.630)\end{array}$ & $\begin{array}{l}-0.194^{* * *} \\
(0.049)\end{array}$ & $\begin{array}{c}-19.053^{* * *} \\
(2.861)\end{array}$ \\
\hline Per capita household income (in 1,000 birr) & $\begin{array}{l}-0.087 \\
(0.156)\end{array}$ & $\begin{array}{l}21.245^{* *} \\
(8.605)\end{array}$ & $\begin{array}{c}0.127 \\
(0.141)\end{array}$ & $\begin{array}{l}13.280^{*} \\
(7.886)\end{array}$ \\
\hline Proportion of income from livestock & $\begin{array}{l}0.008^{* *} \\
(0.003)\end{array}$ & $\begin{array}{l}0.109 \\
(0.163)\end{array}$ & $\begin{array}{l}0.000 \\
(0.003)\end{array}$ & $\begin{array}{l}0.165 \\
(0.175)\end{array}$ \\
\hline Cultivated land (acre) & $\begin{array}{c}0.033 \\
(0.030)\end{array}$ & $\begin{array}{l}1.766^{*} \\
(0.963)\end{array}$ & $\begin{array}{c}-0.116^{* * *} \\
(0.041)\end{array}$ & $\begin{array}{l}-3.271^{*} \\
(1.762)\end{array}$ \\
\hline TLU & $\begin{array}{l}-0.012 \\
(0.012)\end{array}$ & $\begin{array}{c}0.344 \\
(0.309)\end{array}$ & $\begin{array}{c}0.007 \\
(0.011)\end{array}$ & $\begin{array}{c}0.144 \\
(0.385)\end{array}$ \\
\hline TLU squared & $\begin{array}{l}0.000 \\
(0.000)\end{array}$ & $\begin{array}{l}-0.003^{*} \\
(0.002)\end{array}$ & $\begin{array}{c}0.000 \\
(0.000)\end{array}$ & $\begin{array}{l}-0.001 \\
(0.002)\end{array}$ \\
\hline Wealth index & $\begin{array}{l}0.046 \\
(0.038)\end{array}$ & $\begin{array}{l}2.874^{* * *} \\
(1.374)\end{array}$ & $\begin{array}{l}-0.069 \\
(0.070)\end{array}$ & $\begin{array}{l}9.660^{* *} \\
(3.930)\end{array}$ \\
\hline HH size & $\begin{array}{l}-0.023 \\
(0.031)\end{array}$ & $\begin{array}{c}4.264 \\
(2.708)\end{array}$ & $\begin{array}{c}0.008 \\
(0.035)\end{array}$ & $\begin{array}{c}0.083 \\
(1.724)\end{array}$ \\
\hline Head age & $\begin{array}{l}-0.009 \\
(0.021)\end{array}$ & $\begin{array}{c}2.121 \\
(1.786)\end{array}$ & $\begin{array}{l}-0.026 \\
(0.028)\end{array}$ & $\begin{array}{c}0.613 \\
(1.159)\end{array}$ \\
\hline Head age squared & $\begin{array}{c}0.000 \\
(0.000)\end{array}$ & $\begin{array}{l}-0.021 \\
(0.015)\end{array}$ & $\begin{array}{c}0.000 \\
(0.000)\end{array}$ & $\begin{array}{l}-0.003 \\
(0.009)\end{array}$ \\
\hline Head male $(=1)$ & $\begin{array}{c}0.086 \\
(0.183)\end{array}$ & $\begin{array}{l}29.431^{* *} \\
(12.353)\end{array}$ & $\begin{array}{c}-0.373^{* *} \\
(0.156)\end{array}$ & $\begin{array}{c}13.963 \\
(10.065)\end{array}$ \\
\hline Head completed years of education & $\begin{array}{c}0.012 \\
(0.029)\end{array}$ & $\begin{array}{l}-7.536^{* * *} \\
(2.349)\end{array}$ & $\begin{array}{c}-0.127^{* *} \\
(0.060)\end{array}$ & $\begin{array}{l}-2.988 \\
(2.157)\end{array}$ \\
\hline Expected mortality rate & $\begin{array}{l}-0.001 \\
(0.002)\end{array}$ & $\begin{array}{l}-0.090 \\
(0.108)\end{array}$ & $\begin{array}{c}0.002 \\
(0.003)\end{array}$ & $\begin{array}{l}-0.200 \\
(0.125)\end{array}$ \\
\hline Expected livestock price (unchange) $(=1)^{\mathrm{a}}$ & $\begin{array}{l}-0.087 \\
(0.278)\end{array}$ & $\begin{array}{c}13.067 \\
(11.463)\end{array}$ & $\begin{array}{l}0.549^{* * *} \\
(0.274)\end{array}$ & $\begin{array}{l}-0.525 \\
(8.332)\end{array}$ \\
\hline Expected livestock price (higher) $(=1)^{\mathrm{a}}$ & $\begin{array}{c}0.193 \\
(0.138)\end{array}$ & $\begin{array}{l}-1.273 \\
(8.182)\end{array}$ & $\begin{array}{c}0.073 \\
(0.204)\end{array}$ & $\begin{array}{l}25.490^{*} \\
(13.758)\end{array}$ \\
\hline Moderate risk averse $(=1)^{\mathrm{b}}$ & $\begin{array}{l}0.020 \\
(0.174)\end{array}$ & $\begin{array}{l}-21.147^{* *} \\
(9.758)\end{array}$ & $\begin{array}{c}0.105 \\
(0.194)\end{array}$ & $\begin{array}{c}6.387 \\
(13.059)\end{array}$ \\
\hline Less risk averse $(=1)^{\mathrm{b}}$ & $\begin{array}{l}-0.127 \\
(0.117)\end{array}$ & $\begin{array}{l}-11.124 \\
(9.560)\end{array}$ & $\begin{array}{c}-0.491^{* * *} \\
(0.201)\end{array}$ & $\begin{array}{l}-18.496 \\
(15.172)\end{array}$ \\
\hline Constant & $\begin{array}{c}1.003 \\
(0.914)\end{array}$ & $\begin{array}{l}-1.457 \\
(56.217)\end{array}$ & $\begin{array}{l}-0.744 \\
(0.819)\end{array}$ & $\begin{array}{c}0.887 \\
(95.815)\end{array}$ \\
\hline Woreda dummies & Yes & Yes & Yes & Yes \\
\hline Observations & 474 & 474 & 474 & 474 \\
\hline
\end{tabular}

Note: Clustered standard errors at the study-site level are in parentheses. ${ }^{* * *} p<0.01,{ }^{* *} p<0.05,{ }^{*} p<0.1$.

${ }^{a}$ The omitted category is that expected livestock price becomes lower.

${ }^{\mathrm{b}}$ The omitted category is extremely risk averse.

the first sales period; $d_{i 2}^{1 *}$ and $d_{i 2}^{0 *}$ are latent variables for the observed demand status during the second sales period with a superscript 1 to represent purchasers and 0 non-purchasers of IBLI in the previous period; $y_{i 2}^{*}$ is the latent variables for the truncated model; $m_{i 2}$ is the vector of household characteristics that prospectively affect demand in the second sales period; $\alpha_{2}^{1}$ and $\alpha_{2}^{0}$ are regime-specific coefficients; and $u_{i 2}^{1}$ and $u_{i 2}^{0}$ are the regime-specific error terms for the second sales period. Error terms $\xi_{i 1}, u_{i 2}^{1}$, and $u_{i 2}^{0}$ are assumed to be jointly and normally distributed with zero mean. The covariance matrix is
$\Omega=\left(\begin{array}{lll}1 & \rho_{u 1} & \rho_{u 0} \\ \rho_{u 1} & 1 & \rho_{01} \\ \rho_{u 0} & \rho_{01} & 1\end{array}\right)$,

where $\rho_{u 1}$ is the correlation between the unobserved characteristics predicting purchase during the first sales period and continuous purchase during the second sales period. A positive covariance estimate suggests inter-period complementarity, perhaps by reducing liquidity constraints on coverage or learning over time. A negative estimate suggests instead that those 
Table 6. Second stage estimation results on demand for IBLI (dynamic endogenous switching double hurdle model)

\begin{tabular}{|c|c|c|c|c|}
\hline Sales period & $1 \mathrm{st}$ & \multicolumn{3}{|c|}{ 2nd } \\
\hline Dependent variable & \multicolumn{3}{|c|}{ Dummy for IBLI purchase } & Total insured herd value \\
\hline Estimation model & \multicolumn{3}{|c|}{ Switching probit } & Truncated regression \\
\hline \multirow[t]{2}{*}{ 1st sales period demand status } & & Purchase & Non-purchase & \\
\hline & (1) & (2) & (3) & (4) \\
\hline \# Correct answer on IBLI quiz: predicted & $\begin{array}{c}-0.263^{*} \\
(0.137)\end{array}$ & $\begin{array}{c}-0.613^{*} \\
(0.367)\end{array}$ & $\begin{array}{c}0.569^{* * *} \\
(0.113)\end{array}$ & $\begin{array}{c}6.011 \\
(4.929)\end{array}$ \\
\hline 1 st period coupon $(=1)$ & $\begin{array}{l}0.401^{*} \\
(0.222)\end{array}$ & $\begin{array}{c}0.243 \\
(1.077)\end{array}$ & $\begin{array}{c}-0.803^{* *} \\
(0.354)\end{array}$ & $\begin{array}{l}-30.380 \\
(18.908)\end{array}$ \\
\hline Household-round-specific premium rate in the 1 st period & $\begin{array}{c}-0.126^{* * *} \\
(0.030)\end{array}$ & $\begin{array}{l}-0.084 \\
(0.120)\end{array}$ & $\begin{array}{c}0.013 \\
(0.045)\end{array}$ & $\begin{array}{l}-4.214 \\
(3.278)\end{array}$ \\
\hline 2 nd period coupon $(=1)$ & & $\begin{array}{l}-1.978 \\
(1.254)\end{array}$ & $\begin{array}{c}0.349 \\
(0.392)\end{array}$ & $\begin{array}{l}-18.950 \\
(53.030)\end{array}$ \\
\hline Household-round-specific premium rate in the 2 nd period & & $\begin{array}{c}-0.651^{* * *} \\
(0.205)\end{array}$ & $\begin{array}{c}-0.144^{* * * *} \\
(0.044)\end{array}$ & $\begin{array}{c}-15.128^{* * * *} \\
(2.856)\end{array}$ \\
\hline Per capita household income (in 1,000 birr) & $\begin{array}{l}-0.090 \\
(0.152)\end{array}$ & $\begin{array}{l}2.451^{* * *} \\
(0.859)\end{array}$ & $\begin{array}{c}0.060 \\
(0.159)\end{array}$ & $\begin{array}{l}10.982 \\
(8.084)\end{array}$ \\
\hline Proportion of income from livestock & $\begin{array}{l}0.008^{* *} \\
(0.003)\end{array}$ & $\begin{array}{l}0.030^{* *} \\
(0.013)\end{array}$ & $\begin{array}{c}-0.004 \\
(0.003)\end{array}$ & $\begin{array}{c}0.184 \\
(0.135)\end{array}$ \\
\hline Cultivated land (acre) & $\begin{array}{c}0.038 \\
(0.031)\end{array}$ & $\begin{array}{c}-0.407^{* * *} \\
(0.106)\end{array}$ & $\begin{array}{c}-0.087^{* * *} \\
(0.033)\end{array}$ & $\begin{array}{l}-2.202 \\
(1.569)\end{array}$ \\
\hline TLU & $\begin{array}{l}-0.012 \\
(0.012)\end{array}$ & $\begin{array}{l}-0.046 \\
(0.030)\end{array}$ & $\begin{array}{l}0.025^{* *} \\
(0.010)\end{array}$ & $\begin{array}{c}0.222 \\
(0.352)\end{array}$ \\
\hline TLU squared $(/ 1,000)$ & $\begin{array}{c}0.119 \\
(0.091)\end{array}$ & $\begin{array}{l}0.656^{* * *} \\
(0.227)\end{array}$ & $\begin{array}{l}-0.177^{*} \\
(0.101)\end{array}$ & $\begin{array}{l}-0.857 \\
(1.700)\end{array}$ \\
\hline Wealth index & $\begin{array}{c}0.044 \\
(0.041)\end{array}$ & $\begin{array}{l}-0.188 \\
(0.132)\end{array}$ & $\begin{array}{c}-0.239^{\text {*** }} \\
(0.081)\end{array}$ & $\begin{array}{l}7.909^{* *} \\
(3.691)\end{array}$ \\
\hline $\mathrm{HH}$ size & $\begin{array}{l}-0.024 \\
(0.030)\end{array}$ & $\begin{array}{c}0.129 \\
(0.099)\end{array}$ & $\begin{array}{l}-0.012 \\
(0.041)\end{array}$ & $\begin{array}{l}-0.737 \\
(1.470)\end{array}$ \\
\hline Head age & $\begin{array}{l}-0.008 \\
(0.023)\end{array}$ & $\begin{array}{c}0.010 \\
(0.048)\end{array}$ & $\begin{array}{l}-0.021 \\
(0.035)\end{array}$ & $\begin{array}{c}0.581 \\
(1.019)\end{array}$ \\
\hline Head age squared & $\begin{array}{c}0.000 \\
(0.000)\end{array}$ & $\begin{array}{l}-0.001 \\
(0.000)\end{array}$ & $\begin{array}{c}0.000 \\
(0.000)\end{array}$ & $\begin{array}{l}-0.003 \\
(0.009)\end{array}$ \\
\hline Head male $(=1)$ & $\begin{array}{c}0.074 \\
(0.165)\end{array}$ & $\begin{array}{c}0.138 \\
(0.738)\end{array}$ & $\begin{array}{c}-0.556^{* * *} \\
(0.187)\end{array}$ & $\begin{array}{r}10.769 \\
(9.763)\end{array}$ \\
\hline Head completed years of education & $\begin{array}{c}0.009 \\
(0.027)\end{array}$ & $\begin{array}{c}-0.436^{* * *} \\
(0.143)\end{array}$ & $\begin{array}{l}-0.150^{*} \\
(0.079)\end{array}$ & $\begin{array}{l}-2.446 \\
(2.454)\end{array}$ \\
\hline Expected mortality rate & $\begin{array}{l}-0.000 \\
(0.002)\end{array}$ & $\begin{array}{l}-0.005 \\
(0.008)\end{array}$ & $\begin{array}{c}0.003 \\
(0.004)\end{array}$ & $\begin{array}{l}-0.130 \\
(0.118)\end{array}$ \\
\hline Expected livestock price (unchange) $(=1)^{\mathrm{a}}$ & $\begin{array}{l}-0.062 \\
(0.240)\end{array}$ & $\begin{array}{l}-0.079 \\
(0.618)\end{array}$ & $\begin{array}{l}0.660^{* *} \\
(0.294)\end{array}$ & $\begin{array}{l}-2.910 \\
(9.232)\end{array}$ \\
\hline Expected livestock price (higher) $(=1)^{\mathrm{a}}$ & $\begin{array}{l}0.231^{*} \\
(0.135)\end{array}$ & $\begin{array}{l}-0.130 \\
(0.397)\end{array}$ & $\begin{array}{c}0.064 \\
(0.195)\end{array}$ & $\begin{array}{c}17.693 \\
(13.519)\end{array}$ \\
\hline Moderate risk averse $(=1)^{\mathrm{b}}$ & $\begin{array}{c}0.018 \\
(0.176)\end{array}$ & $\begin{array}{l}-0.159 \\
(0.431)\end{array}$ & $\begin{array}{c}0.120 \\
(0.158)\end{array}$ & $\begin{array}{c}7.596 \\
(11.895)\end{array}$ \\
\hline Less risk averse $(=1)^{\mathrm{b}}$ & $\begin{array}{l}-0.118 \\
(0.113)\end{array}$ & $\begin{array}{l}-0.602 \\
(0.601)\end{array}$ & $\begin{array}{l}-0.382^{*} \\
(0.213)\end{array}$ & $\begin{array}{l}-14.431 \\
(14.325)\end{array}$ \\
\hline Constant & $\begin{array}{c}0.891 \\
(0.884)\end{array}$ & $\begin{array}{c}3.411 \\
(2.822)\end{array}$ & $\begin{array}{c}-2.473^{* * *} \\
(0.730)\end{array}$ & $\begin{array}{c}32.847 \\
(66.968)\end{array}$ \\
\hline $\begin{array}{l}\text { Woreda dummy variables } \\
\rho_{u 1}\end{array}$ & Yes & $\begin{array}{c}\text { Yes } \\
-0.326^{* *} \\
(0.151)\end{array}$ & Yes & Yes \\
\hline$\rho_{u 0}$ & & & $\begin{array}{l}-14.813 \\
(98.551)\end{array}$ & \\
\hline Observations & 474 & 474 & 474 & 474 \\
\hline
\end{tabular}

Note: Clustered standard errors at the study-site level are in parentheses. ${ }^{* * *} p<0.01,{ }^{* *} p<0.05,{ }^{*} p<0.1$.

${ }^{a}$ The omitted category is that expected livestock price becomes lower.

${ }^{\mathrm{b}}$ The omitted category is extremely risk averse. 
who purchased IBLI at the first period are less likely to adopt in the second. The parameter $\rho_{u 0}$ represents the correlation between non-purchase during the first sales period and new purchase during the second sales period. Since $d_{i 2}^{1 *}$ and $d_{i 2}^{0 *}$ are never observed simultaneously, the joint distribution of $\left(u_{i 2}^{1}, u_{i 2}^{0}\right)$, and consequently, $\rho_{01}$ cannot be identified, so we have to impose the assumption of unit variance. The model is estimable via a full information maximum likelihood switching probit model. ${ }^{18}$ We then estimate the separate truncated regression in Eqn. (6) to examine factors determining TIHV at the second sales period, conditional on purchase.

In the second sales period estimation, we add the discount premium rate and the dummy for coupon recipient in the previous sales period to the vector of regressors, allowing for persistence in the effect of initial sales period treatments in subsequent sales periods. This allows for the possibility that one-off subsidies on a product might reduce future demand as the reduced price creates a focal point for purchasers who then become unwilling to pay more for the product later (Dupas, 2014; Fischer et al., 2014). Such price anchoring effects could offset the hypothesized learning effects that motivate short-run subsidies to increase uptake temporarily in the hope that purchasers induced by the subsidy to experiment will learn from the experience, thereby permanently increasing demand for the product. Because our data do not cover nonoverlapping contract periods, we cannot test the learning hypothesis to establish whether temporary price discounts indeed induce permanently increased uptake through learning. But we can test whether one-shot price subsidies have immediate impacts on uptake through the coefficient estimates on the current period discount rate, while also testing whether subsidies have longer term price anchoring effects that permanently decrease demand via the coefficient estimates on the previous period discount rate, holding current (potentially subsidized) price constant. ${ }^{19}$

The results are presented in Table 6. The qualitative inference for the first sales period (Column 1) is quite similar to the previous findings of the static model. But we can now infer something about the dynamic pattern of IBLI uptake based on the correlation of the error terms $\left(\rho_{u 1}, \rho_{u 0}\right)$. Among the first period purchasers (Column 2), the correlation coefficient of the first and second period purchase $\left(\rho_{u 1}\right)$ is negative and statistically significant, implying that those who purchased IBLI during the first sales period are somewhat less likely to buy it again in the subsequent period. This may reflect satiation because two successive policies have an overlapping coverage period or it might indicate that those who have purchased insurance tend subsequently to opt not to purchase insurance, signaling negative learning effects. Unfortunately, in these data we cannot disentangle which effect generates this result. It will take a longer panel to disentangle those effects.

The coefficient estimated on the first period coupon dummy is negative and significant for first sales period non-purchasers (Column 3). This seems to indicate that if someone was likely to purchase, it was likely to occur when they received a coupon, so having not purchased when one got a coupon is an especially good predictor that one is not likely to purchase later. The (potentially discounted) price in the first sales period has no statistically significant effect on the second sales period decision to purchase in terms of either probability or volume, indicating that there is no price anchoring effect. ${ }^{20}$ If the reduced price during the first sales period induces greater uptake and experience with the product leads to positive learning effects on demand, then the net null effects of the price in the first sales period could signal that learning effects and anchoring effects cancel out each other. ${ }^{21}$ If that were the case, however, anchoring effects should dominate learning effects for those who did not buy IBLI in the first period because they had few opportunities to learn. Our switching probit model result (Table 6) indicates that conditional on the current subsidy level, the previous price affects the current demand for neither purchasers nor non-purchasers in the previous round, which supports our interpretation of no anchoring effects.

The factors associated with purchase during the second sales period differ between early adopters who purchased during the first sales period and non-adopters who did not purchase during the first sales period. For example, accurate knowledge of IBLI is not associated with increased IBLI purchase in the second sales period if a household has already bought insurance in the previous period, while it does for a household who has not previously purchased IBLI. Livestock holdings are statistically significantly associated with the probability of buying IBLI, once error terms are allowed to be correlated over time. Interestingly, their relationship is not monotonic, but Ushaped for early adopters and inverse-U-shaped for early non-adopters. The inverted U-shaped demand for early nonadopters seems to be consistent with the traditional view of multiple herd size equilibria, where the demand for IBLI is highest among pastoralists with herd size slightly greater than the threshold at which herd dynamics bifurcate in order to avoid falling into a poverty trap (Carter \& Barrett, 2006; Lybbert et al., 2004; Santos \& Barrett, 2011). On the other hand, U-shaped demand for early adapters supports Janzen, Carter, and Ikegami (2013)'s prediction that vulnerable households with livestock holding just above the critical threshold demand index-based asset insurance less due to basis risk and purchase of productive assets instead.

\section{CONCLUSIONS}

Index insurance is increasingly recognized as a promising means of protecting the poor from losses associated with climate shocks. Attempts have been made worldwide in the past decade to introduce innovative index-based weather insurance products that should be free from the classical incentive problems and high transactions costs characteristic of conventional indemnity insurance. These products have, however, commonly suffered from low uptake rates that may be due to their coverage of transitory income losses associated with crop failure, rather than asset loss that leads to permanent income decline.

We study demand for a new index-based livestock insurance (IBLI) product introduced in southern Ethiopia among pastoralists, whose permanent incomes depend heavily on livestock, in an attempt to explore factors underlying the demand for asset index insurance. We focus specifically on the role of product knowledge and price in uptake decisions, exploiting the random assignment of learning kits and discount coupons to identify estimates of the causal relationships between those factors and IBLI demand.

We find that IBLI uptake rates, approaching $30 \%$ in the initial year of product offer, exceed that of most other indexbased insurance products in their pilot periods. Our estimation results show that consumer education through the provision of skit audio tapes and comics improves knowledge of the product, but that a more accurate understanding of IBLI does not necessarily have significant causal impacts on uptake. Although several prior studies conjecture that lack of understanding of the index insurance product is a key constraint on adoption, and indeed our survey respondents also reported 
it as a main reason for not purchasing IBLI, our empirical evidence does not strongly support this argument.

On the other hand, we find that price incentives created through discount coupons effectively and substantially increase current period uptake rates without lowering future demand by creating a low price reference point. Since these effects exist for both those who purchased and those who did not in the first sales period, it appears that a temporary subsidy does not create price anchoring effects that might subsequently depress demand. Our results, however, derive from a two sales period setting, so the longer term effects of price reductions remain ambiguous.

Indeed, one of the limitations of our study is that we do not observe longer panel data. We find decreasing uptake rates over time as well as some evidence suggesting that those who purchased IBLI previously are less likely to buy it in the subsequent period. We cannot identify, however, whether this is because IBLI policies have overlapping contract periods or those who have purchased IBLI tend to disadopt IBLI after having experimented with it. Gaining a firmer understanding of the longer term demand and uptake patterns is a topic for future research when longer panel data become available.

Also, in contrast to our a priori expectation, we find that the education level of a household head is negatively correlated with IBLI uptake. We hypothesize that educated household heads may have alternative sources of formal or informal insurance, which reduces their demand for IBLI. But the exact mechanism remains uncertain and a topic for future research.

\section{NOTES}

1. Woreda is the third-level administrative unit of Ethiopia after the regional state and zone, and can be subdivided into kebele and further into reera.

\section{These nominal values are constant across sales periods.}

3. One USD is equivalent to 17.42 Ethiopian birr as of February 2012.

4. More specifically, woreda-specific premium rates, which are close to actuarially fair premium rates, are as follows: $9.75 \%$ for Dilo, $8.71 \%$ for Teltele, $7.54 \%$ for Yabello, $9.49 \%$ for Dire, $8.58 \%$ for Arero, $9.36 \%$ for Dhas, and $11.05 \%$ for Miyo and Moyale.

5. The basic characteristics of those households who remain in the sample are quite similar to those that drop out. Also, we have re-estimated some models, such as those reported in Table 4, and found that the inverse Mills ratio constructed from the first-stage selection model, whose dependent variable takes one if the household remains in the sample, is statistically insignificant, indicating that the sample attrition is not problematic. For ease of discussion, we do not include the selectioncorrection term in our main regressions.

\section{One TLU is equivalent to one cow, 0.7 camel, 10 goat, or 10 sheep.}

7. Discount coupons were printed in $10 \%$ intervals between $10 \%$ and $80 \%$ with roughly one tenth of the sampled households falling into each interval. In parallel with the household survey for this study, a separate but overlapping herd migration survey was conducted which included 20 households from our larger sample. Ten of those households received $100 \%$ discount rates.

8. There were some mismatches between self-reports and administrative records on IBLI purchase. After careful verification through detailed discussions with both OIC and respondents, we made corrections for those mismatched values to reflect the reality.

9. For households that did not receive a discount coupon, their premium rate is equivalent to the woreda-specific premium rate. Premium rates at the woreda level did not vary with sales period, while the discount rates at the household level varied with the sales period.

10. We investigated the appropriateness of the standard Tobit versus the double hurdle $(\mathrm{DH})$ model using a likelihood ratio (LR) test. The LR values are 161.4 and 139.5 for the first and second sales period, respectively, which yield $p$-values of essentially zero. We therefore reject the standard Tobit model.
11. The conditional independence assumption can be relaxed if one has a variable that affects the participation decision but not the amount decision, and so can be validly excluded from the amount decision equation. The inverse Mills ratio from the participation decision probit is then included in the amount decision equation to control for potential error dependence in a procedure that is mechanically identical to a Heckman selection model. (Note, however, that the motivation for a Heckman selection model is typically censoring of the dependent variable, not a corner solution dependent variable as is the case in the current application.) Although both the DH and Heckman selection-like model are appropriate in our context, we do not have the relevant exclusion restrictions to estimate the Heckman selection-like model; we therefore rely on the $\mathrm{DH}$ model, despite the underlying assumption of error independence.

12. We again use the administrative "intent-to-treat" record for these variables, instead of respondents' self-reporting.

13. We do not use an estimated cardinal value of risk preference, such as the midpoints of the imputed constant relative risk aversion (CRRA) intervals, because that method would impose strong assumptions about the shape of preferences and may not precisely reflect Arrow-Pratt risk preferences if there exist any threshold effects in underlying wealth dynamics (Lybbert, Just, \& Barrett, 2013), as prior empirical studies of herd wealth dynamics in this region show (Lybbert et al., 2004; Santos \& Barrett, 2011).

14. Table 9 shows the result of balancing test by encouragement intervention at each sales period. The numbers indicate the mean differences between treatment and control groups, with $p$-values in parentheses. While a few variables show statistically significant differences across the treatment conditions, most variables are well-balanced. Furthermore, when we run the regression of a dummy variable for treatment on the full set of covariates, we cannot reject the joint null hypothesis that the covariates are orthogonal to treatment condition, thus establishing the balance in the experimental sample.

15. These marginal impacts reflect unconditional average partial effects of the discount premium rate on IBLI demand. The marginal impacts on the value of insured animal conditional on purchase of IBLI are -3.12 and -2.75 in the first and second period, respectively. These estimates are obtained using the craggit user-written command in Stata (Burke, 2009).

16. We re-estimated the model with the coupon dummy and the discounted premium rates based on self-reports, rather than administrative records, for both the prediction of the number of correct quiz answers and the demand for IBLI. The results, presented in Panel B of Table 10, 
show mixed effects of the coupon dummy. While coupon recipients are more likely to purchase IBLI, they tend to insure fewer animals. On the one hand, coupon recipients may be further encouraged though conversation by DAs and ILRI staff to buy IBLI when they receive the coupon. On the other hand, however, self-motivated people, who are willing to buy IBLI even without the discount coupon, tend to buy more IBLI than those motivated by the experiments. These effects may be opposing in the different sales period.

17. The results hold true when we instead use self-reported coupon receipts (instead of administrative data) and the actual number of correct quiz answers, rather than the instrumented value, especially in the second sales period, as shown in Table 10 .
18. Although the use of instruments is recommended, the model is identified by non-linearity even if the vector of observables perfectly overlap in Eqns. (3)-(5) (Lokshin \& Glinskaya, 2009).

19. We did not include these variables in the static model so as to make variables perfectly comparable between the first and second sales periods.

20. Because we control for the second-period price, inclusion of either the first-period price or the difference between the second-period and firstperiod prices as an additional regressor does not qualitatively alter the results.

21. We thank an anonymous reviewer for pointing out this possibility.

\section{REFERENCES}

Barnett, B. J., Barrett, C. B., \& Skees, J. R. (2008). Poverty traps and index-based risk transfer products. World Development, 36(10), $1766-1785$.

Barrett, C. B. (2011). Covariate catastrophic risk management in the developing world: Discussion. American Journal of Agricultural Economics, 93(2), 512-513.

Barrett, C. B., \& Santos, P. (2014). The impact of changing rainfall variability on resource-dependent wealth dynamics. Ecological Economics, 105, 48-54.

Bhattamishra, R., \& Barrett, C. B. (2010). Community-based risk management arrangements: A review. World Development, 38(7), 923-932.

Biener, C. (2013). Pricing in microinsurance markets. World Development, 41, 132-144.

Binswanger, H. P. (1980). Attitudes toward risk: Experimental measurement in rural India. American Journal of Agricultural Economics, 62(3), 395-407.

Burke, W. J. (2009). Fitting and interpreting Cragg's Tobit alternative using Stata. Stata Journal, 9(4), 584-592.

Cai, J., de Janvry, A., \& Sadoulet, E. (2015). Social networks and the decision to insure. American Economic Journal: Applied Economics, 7(2), 81-108.

Carter, M. R., \& Barrett, C. B. (2006). The economics of poverty traps and persistent poverty: An asset-based approach. Journal of Development Studies, 42(2), 178-199.

Carter, M. R., Little, P. D., Mogues, T., \& Negatu, W. (2007). Poverty traps and natural disasters in Ethiopia and Honduras. World Development, 35(5), 835-856.

Chantarat, S., Mude, A. G., Barrett, C. B., \& Carter, M. R. (2013). Designing index-based livestock insurance for managing asset risk in northern Kenya. Journal of Risk and Insurance, 80(1), 205-237.

Churchill, C. (2006). Protecting the poor: A micro-insurance compendium. Geneva: International Labour Office.

Cole, S., Giné, X., Tobacman, J., Topalova, P., Townsend, R., \& Vickery, J. (2013). Barriers to household risk management: Evidence from India. American Economic Journal: Applied Economics, 5(1), 104-135.

Cragg, J. G. (1971). Some statistical models for limited dependent variables with application to the demand for durable goods. Econometrica, 39(5), 829-844

de Bock, O., \& Gelade, W. (2012). The demand for micro-insurance: A literature review ILO research paper 26. Geneva: International Labour Organization.

Dercon, S., \& Krishnan, P. (2000). In sickness and in health: Risk sharing within households in rural Ethiopia. Journal of Political Economy, 108 (4), 688-727.

Desta, S., Berhanu, W., Gebru, G., \& Amosha, D. (2008). Pastoral drop out study in selected weredas of Borana zone Oromia regional state. CARE/USAID, <http://www.disasterriskreduction.net/fileadmin/ user_upload/drought/docs/Pastoral Dropout Study_ _ Final Version. $\mathrm{pdf}>$.

di Falco, S., \& Bulte, E. (2013). The impact of kinship networks on the adoption of risk-mitigating strategies in Ethiopia. World Development, 43, 100-110.

Dupas, P. (2014). Short-run subsidies and long-run adoption of new health products: Evidence from a field experiment. Econometrica, 82(1), $197-28$.
Fischer, G., McConnell, M., Karlan,D., \& Raffler, P. (2014). To charge or not to charge: Evidence from a health products experiment in Uganda. NBER working paper no. 20170.

Garcia, J., \& Labeaga, J. M. (1996). Alternative approaches to modelling zero expenditure: An application to Spanish demand for tobacco. Oxford Bulletin of Economics and Statistics, 58(3), 489-506.

Gaurav, S., Cole, S., \& Tobacman, J. (2011). Marketing complex financial products in emerging markets: Evidence from rainfall insurance in India. Journal of Marketing Research, 48, S150-S162.

Giesbert, L., Steiner, S., \& Bendig, M. (2011). Participation in micro life insurance and the use of other financial services in Ghana. Journal of Risk and Insurance, 78, 7-35.

Giné, X., Townsend, R., \& Vickery, J. (2008). Patterns of rainfall insurance participation in rural India. World Bank Economic Review, 22(3), 539-566.

Giné, X., \& Yang, D. (2009). Insurance, credit, and technology adoption: Field experimental evidence from Malawi?. Journal of Development Economics, 89, 1-11.

Huysentruyt, M., Barrett, C. B., \& McPeak, J. G. (2009). Understanding declining mobility and interhousehold transfers among east African pastoralists. Economica, 76(32), 315-336.

Janzen, S. A., Carter, M. R., \& Ikegami, M. (2013). Valuing asset insurance in the presence of poverty traps. Retrieved from <http:// www.montana.edu/econ/sjanzen/valuingassetinsurance.pdf $>$.

Jensen, N., Barrett, C. B., \& Mude, A. (2014). Basis risk and the welfare gains from index insurance: Evidence from northern Kenya Mimeo. Ithaca: Cornell University.

Jensen, N., Mude, A., \& Barrett, C. B. (2014). How basis risk and spatiotemporal adverse selection influence demand for index insurance: Evidence from northern Kenya Mimeo. Ithaca: Cornell University.

Jones, A. (1992). A note on computation of the double-hurdle model with dependence with an application to tobacco expenditure. Bulletin of Economic Research, 44(1), 67-74.

Jowett, M. (2003). Do informal risk sharing networks crowd out public voluntary health insurance? Evidence from Vietnam. Applied Economics, 35, 1153-1161.

Karlan, D., Osei, R., Osei-Akoto, I., \& Udry, C. (2014). Agricultural decisions after relaxing credit and risk constraints. Quarterly Journal of Economics, 129(2), 597-652.

Leblois, A., Quirion, P., Alhassane, A., \& Traoré, S. (2014). Weather index drought insurance: An ex ante evaluation for millet growers in Niger. Environmental Resource Economics, 57, 527-551.

Lokshin, M., \& Glinskaya, E. (2009). The effect of male migration on employment patterns of women in Nepal. World Bank Economic Review, 23(3), 481-507.

Lybbert, T. J., Barrett, C. B., Desta, S., \& Coppock, L. D. (2004). Stochastic wealth dynamics and risk management among a poor population. Economic Journal, 114(498), 750-777.

Lybbert, T. J., Just, D. R., \& Barrett, C. B. (2013). Estimating risk preferences in the presence of bifurcated wealth dynamics: Can we identify static risk aversion amidst dynamic risk responses?. European Review of Agricultural Economics, 40(2), 361-377.

Matul, M., Dalal, A., de Bock, O., \& Gelade, W. (2013). Why people do not buy microinsurance and what can we do about it ILO microinsurance paper 20. Geneva: International Labour Organization. 
McIntosh, C., Sarris, A., \& Papadopoulos, F. (2013). Productivity, credit, risk, and the demand for weather index insurance in smallholder agriculture in Ethiopia. Agricultural Economics, 44(4-5), 399-417.

McPeak, J. (2004). Contrasting income shocks with asset shocks: Livestock sales in northern Kenya. Oxford Economic Papers, 56(2), 263-284.

McPeak, J., Chantarat, S., \& Mude, A. G. (2010). Explaining index based livestock insurance to pastoralists. Agricultural Finance Review, 70(3), $333-352$.

Megeresa, B., Markemann, A., Angassa, A., \& Zárate, A. V. (2013). The role of livestock diversification in ensuring household food security under a changing climate in Borana, Ethiopia. Food Security, 6(1), $15-28$.

Miranda, M. J., \& Farrin, K. (2012). Index insurance for developing countries. Applied Economic Perspectives and Policy, 34(3), 391-427.

Morduch, J. (1995). Income smoothing and consumption smoothing. Journal of Economic Perspectives, 9(3), 103-114.

Morduch, J. (2006). Micro-insurance: The next revolution. In A. Banerjee, R. Benabou, \& D. Mookherjee (Eds.), Understanding poverty. New York: Oxford University Press.

Mude, A. G., Chantarat, S., Barrett, C. B., Carter, M. R., Ikegami, M., \& McPeak, J. (2012). Insuring against drought-related livestock mortality: Piloting index-based livestock Insurance in northern Kenya. In E. Makaudze (Ed.), Weather index insurance for smallholder farmers in Africa: Lessons learnt and goals for the future. South Africa: African SUN MeDIA.

Ricker-Gilbert, J., Jayne, T. S., \& Chirwa, E. (2011). Subsidies and crowding out: A double-hurdle model of fertilizer demand in Malawi. American Journal of Agricultural Economics, 93(1), 26-42.
Rosenzweig, M. R., \& Wolpin, K. I. (1993). Credit market constraints, consumption smoothing, and the accumulation of durable production assets in low-income countries: Investment in bullocks in India. Journal of Political Economy, 101(2), 223-244.

Sahn, D. E., \& Stifel, D. C. (2000). Poverty comparisons over time and across countries in Africa. World Development, 28(12), 25-46.

Santos, P., \& Barrett, C. B. (2011). Persistent poverty and informal credit. Journal of Development Economics, 96(2), 37-347.

Skees, J. R. (2008). Innovations in index insurance for the poor in lower income countries. Agricultural and Resource Economics Review, 37(1), $1-15$.

Tache, B. (2008). Pastoralism under stress: Resources, institutions, and poverty among the Borana Oromo in southern Ethiopia (Ph.D. thesis). Norway: Norwegian University of Life Sciences.

Townsend, R. (1994). Risk and insurance in village India. Econometrica, 62(3), 539-591.

Udry, C. (1994). Risk and insurance in a rural credit market: An empirical investigation in northern Nigeria. Review of Economic Studies, 61(3), 495-526.

Zant, W. (2008). Hot stuff: Index insurance for Indian smallholder pepper growers. World Development, 36(9), 1585-1606.

Table 7. Number of sample households that received a discount coupon

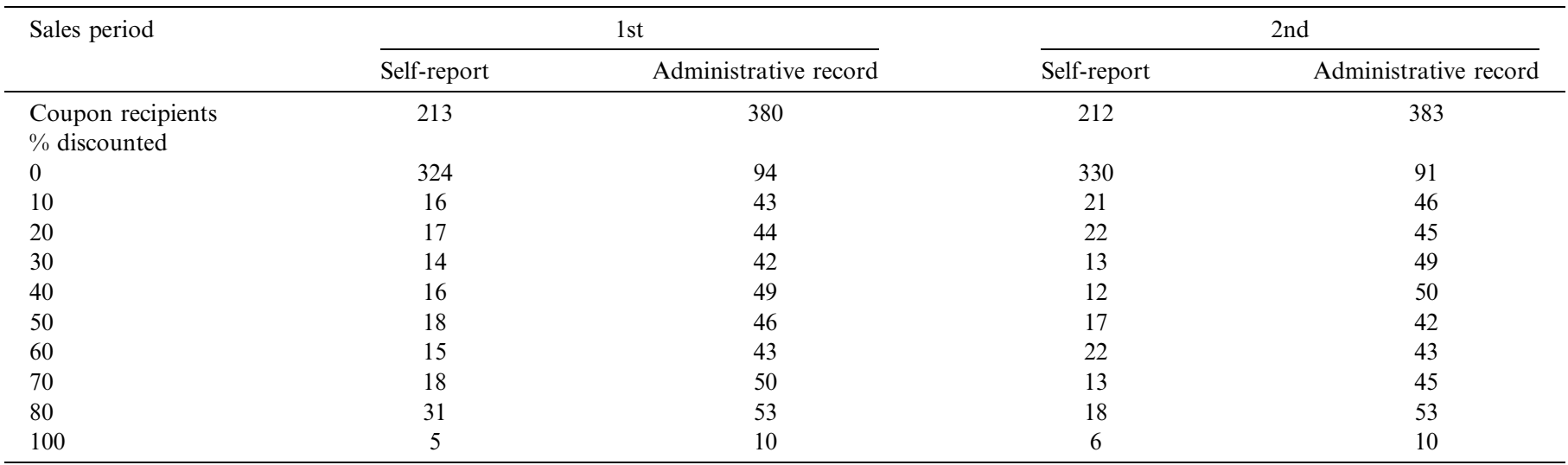

Table 8. Definition of variables in the regression analysis

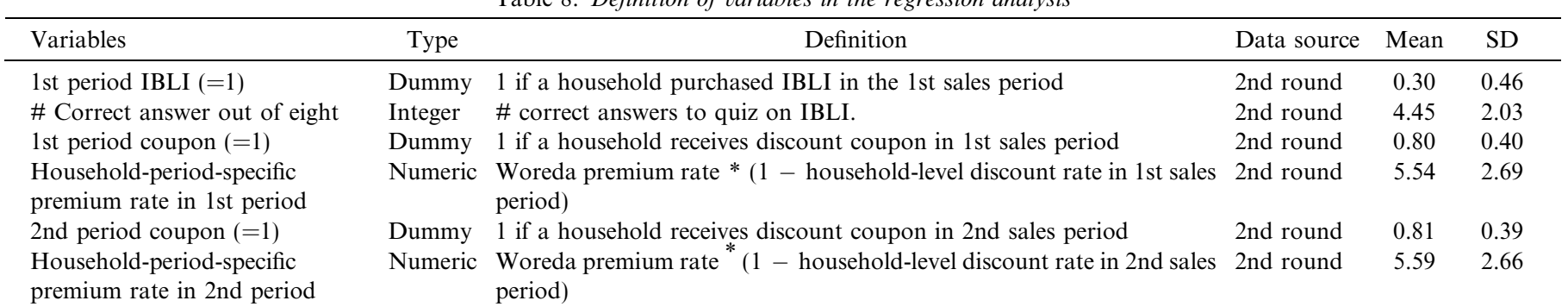


Table 8 (continued)

\begin{tabular}{|c|c|c|c|c|c|}
\hline Variables & Type & Definition & Data source & Mean & SD \\
\hline Moderate risk averse & Dummy & $\begin{array}{l}\text { In the field risk tolerance is elicited through the following instruction: } \\
\text { "In this game, I offer a chance for you to choose one of the six lotteries } \\
\text { displayed in the next image, which may allow you to earn from } 0 \text { to } 200 \\
\text { Birr depending on your choice of lottery and your luck. The total amount } \\
\text { of reward you will get will depend on the outcome of the lottery you } \\
\text { choose, which will depend on the outcome of a coin that I am going to flip. } \\
\text { Which game do you want to play?" } \\
\text { Those who choose game (C) or (D) are categorized as moderately risk- } \\
\text { averse } \\
\text { (A) } 5050 \\
\text { (B) } 4595 \\
\text { (C) } 40120 \\
\text { (D) } 30150 \\
\text { (E) } 10190 \\
\text { (F) } 0200\end{array}$ & 1st round & 0.27 & 0.45 \\
\hline Less risk averse & Dummy & $\begin{array}{l}\text { See the definition above. Those who choose game }(\mathrm{E}) \text { or }(\mathrm{F}) \text { are } \\
\text { categorized as less risk-averse. }\end{array}$ & 1st round & 0.36 & 0.48 \\
\hline $\begin{array}{l}\text { Monthly per capita household } \\
\text { income (in } 1000 \text { birr) }\end{array}$ & Numeric & $\begin{array}{l}\text { Monthly per capita household income (in 1,000 birr), including } \\
\text { earnings and self-consumed value of self-employed and employed } \\
\text { agricultural and non-agricultural activities, and non-labor earnings, } \\
\text { such as remittances and governmental assistance }\end{array}$ & 1st round & 467.38 & 466.93 \\
\hline TLU and its squared & Numeric & \# of TLU owned at the time of the baseline survey and its squared & 1st round & 14.68 & 22.20 \\
\hline Wealth index & Numeric & $\begin{array}{l}\text { Wealth index computed by the principal component analysis from } \\
\text { more than } 30 \text { assets, including durables and productive assets, } \\
\text { household facilities }\end{array}$ & 1st round & -0.001 & 1.00 \\
\hline Expected mortality rate & Numeric & $\begin{array}{l}\text { Subjective expected mortality rate within a year elicited at the baseline } \\
\text { survey }\end{array}$ & 1 st round & 48.27 & 28.39 \\
\hline $\begin{array}{l}\text { Expected livestock price (no } \\
\text { change }=1 \text { ) }\end{array}$ & Dummy & $\begin{array}{l}\text { One if a household expects the price of livestock to remain the same } \\
\text { within a year from the baseline survey }\end{array}$ & 1st round & 0.12 & 0.32 \\
\hline $\begin{array}{l}\text { Expected livestock price } \\
\text { (increase }=1 \text { ) }\end{array}$ & Dummy & $\begin{array}{l}\text { One if a household expects the price of livestock to rise within a year } \\
\text { from the baseline survey }\end{array}$ & 1st round & 0.57 & 0.50 \\
\hline Cultivated land (acre) & Numeric & Total cultivated area & 1st round & 1.42 & 2.08 \\
\hline HH size & Integer & The number of household members at the time of the baseline survey & 1st round & 6.26 & 2.49 \\
\hline Head age and its squared & Integer & Age of household head at the time of the baseline survey & 1 st round & 50.21 & 18.15 \\
\hline Head male $(=1)$ & Dummy & One if a household head is male at the time of the baseline survey & 1st round & 0.79 & 0.41 \\
\hline Head education & Integer & $\begin{array}{l}\text { Years of completed education of the household head at the time of the } \\
\text { baseline survey }\end{array}$ & 1st round & 0.50 & 1.83 \\
\hline
\end{tabular}

Table 9. Balancing test across treatment conditions

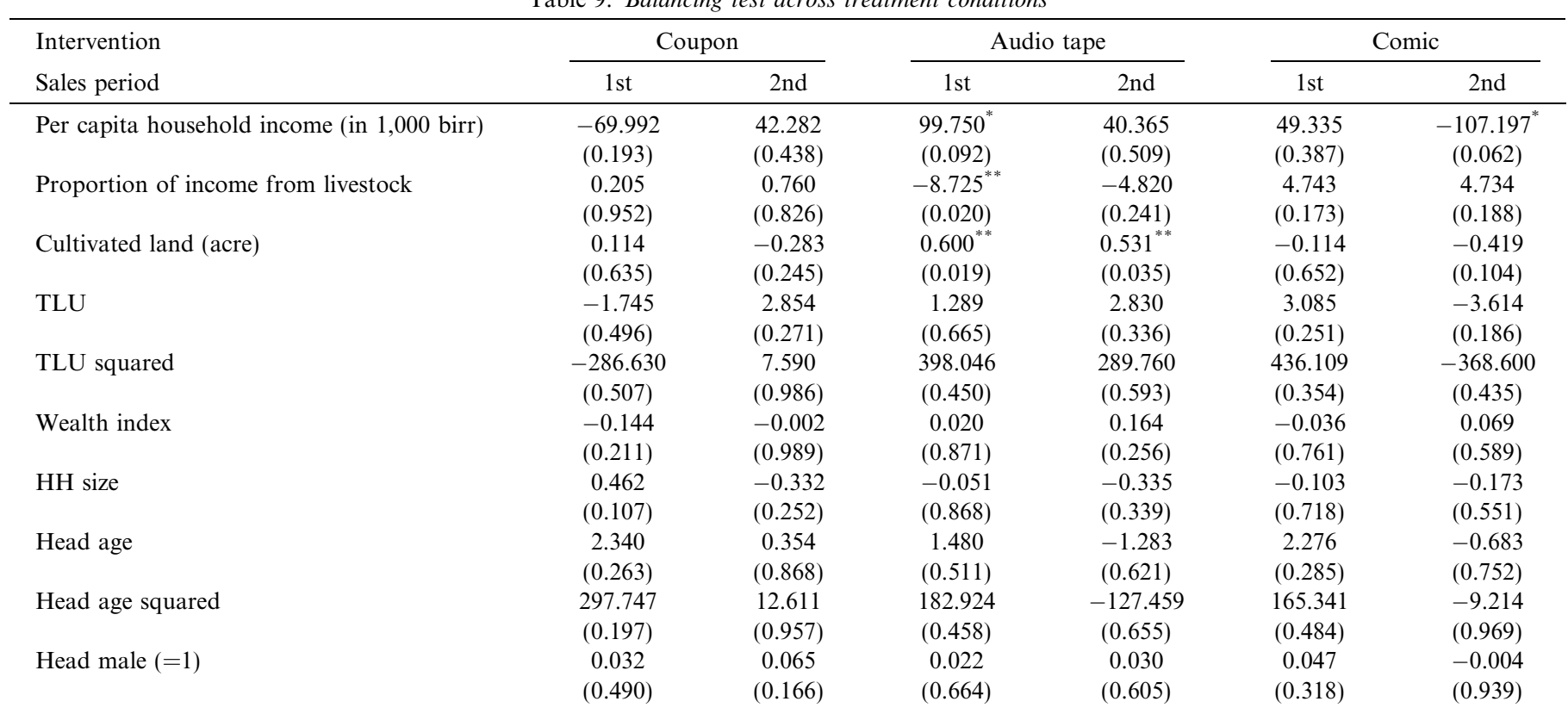


Table 9 (continued)

\begin{tabular}{|c|c|c|c|c|c|c|}
\hline \multirow{2}{*}{$\begin{array}{l}\text { Intervention } \\
\text { Sales period }\end{array}$} & \multicolumn{2}{|c|}{ Coupon } & \multicolumn{2}{|c|}{ Audio tape } & \multicolumn{2}{|c|}{ Comic } \\
\hline & 1 st & 2nd & 1 st & 2nd & 1 st & 2nd \\
\hline \multirow[t]{2}{*}{ Head' completed years of education } & 0.127 & 0.029 & 0.117 & 0.270 & -0.249 & -0.007 \\
\hline & $(0.545)$ & $(0.893)$ & $(0.590)$ & $(0.300)$ & $(0.256)$ & $(0.974)$ \\
\hline Expected mortality rate & $(0.336)$ & $(0.148)$ & $(0.937)$ & $(0.546)$ & $(0.541)$ & $(0.290)$ \\
\hline \multirow[t]{2}{*}{ Expected livestock price (unchange) $(=1)^{\mathrm{a}}$} & 0.001 & $0.074^{* *}$ & 0.066 & -0.031 & 0.009 & -0.054 \\
\hline & $(0.973)$ & $(0.048)$ & $(0.105)$ & $(0.470)$ & $(0.819)$ & $(0.156)$ \\
\hline \multirow[t]{2}{*}{ Moderate risk averse $(=1)^{\mathrm{b}}$} & -0.024 & 0.014 & 0.009 & -0.009 & -0.005 & 0.008 \\
\hline & $(0.647)$ & $(0.786)$ & $(0.877)$ & $(0.891)$ & $(0.917)$ & $(0.880)$ \\
\hline \multirow[t]{2}{*}{ Less risk averse $(=1)^{\mathrm{b}}$} & 0.030 & -0.009 & 0.049 & 0.054 & -0.067 & 0.026 \\
\hline & $(0.584)$ & $(0.877)$ & $(0.419)$ & $(0.428)$ & $(0.228)$ & $(0.652)$ \\
\hline Joint $F$-test $($ Prob $>F)$ & 0.765 & 0.226 & 0.128 & 0.392 & 0.556 & 0.241 \\
\hline
\end{tabular}

Note: $p$-Values are in parenthesis. ${ }^{* * *} p<0.01,{ }^{* *} p<0.05,{ }^{*} p<0.1$.

${ }^{a}$ The omitted category is that expected livestock price becomes lower.

${ }^{b}$ The omitted category is extremely risk averse.

Table 10. Second stage estimation results on demand for IBLI (static double hurdle model) with alternative definition of key variables

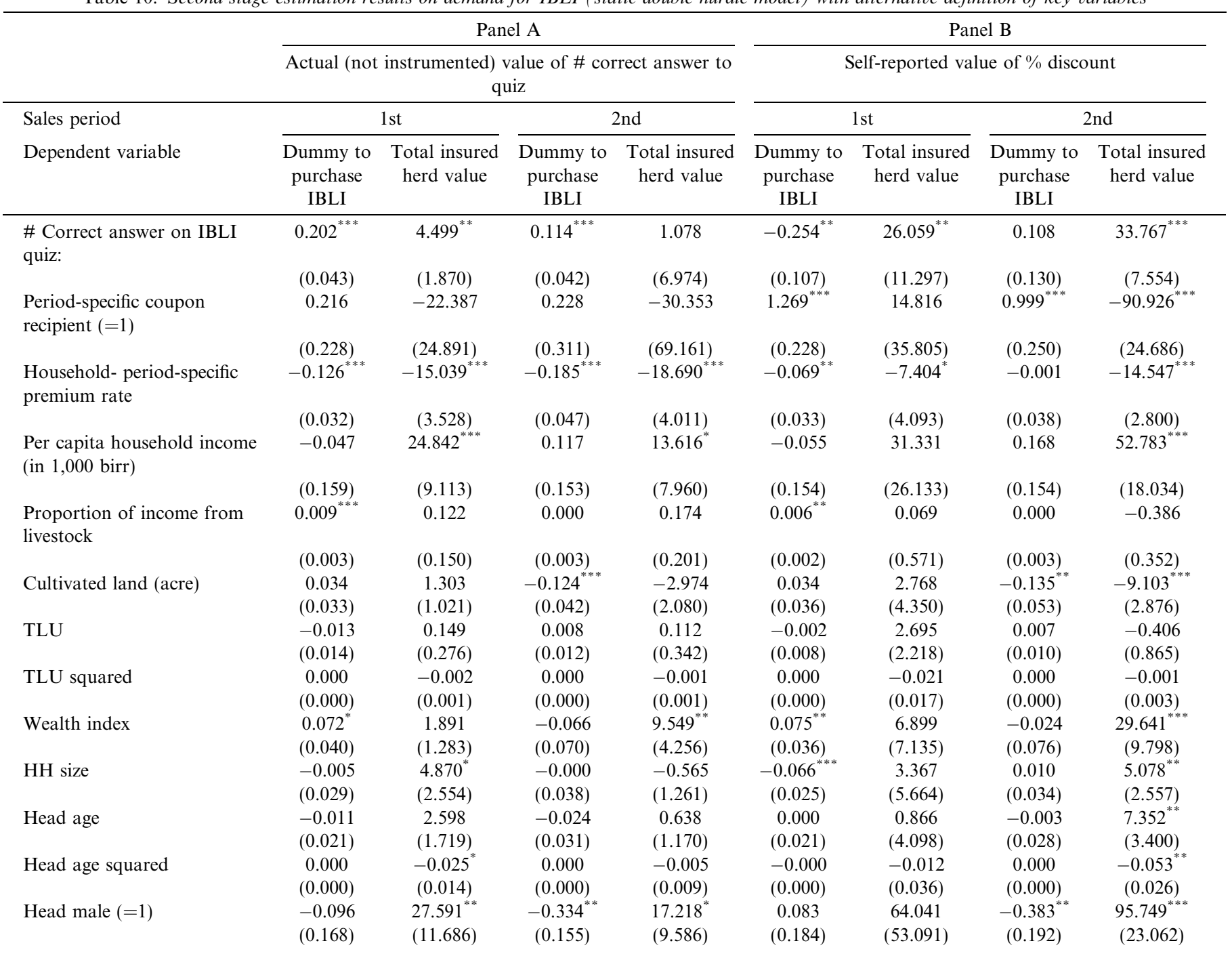

(continued on next page) 
Table 10 (continued)

\begin{tabular}{|c|c|c|c|c|c|c|c|c|}
\hline \multirow{4}{*}{$\begin{array}{l}\text { Sales period } \\
\text { Dependent variable }\end{array}$} & \multicolumn{4}{|c|}{ Panel A } & \multicolumn{4}{|c|}{ Panel B } \\
\hline & \multicolumn{4}{|c|}{$\begin{array}{l}\text { Actual (not instrumented) value of \# correct answer to } \\
\text { quiz }\end{array}$} & \multicolumn{4}{|c|}{ Self-reported value of $\%$ discount } \\
\hline & \multicolumn{2}{|c|}{1 st } & \multicolumn{2}{|c|}{ 2nd } & \multicolumn{2}{|c|}{1 st } & \multicolumn{2}{|c|}{ 2nd } \\
\hline & $\begin{array}{l}\text { Dummy to } \\
\text { purchase } \\
\text { IBLI }\end{array}$ & $\begin{array}{l}\text { Total insured } \\
\text { herd value }\end{array}$ & $\begin{array}{l}\text { Dummy to } \\
\text { purchase } \\
\text { IBLI }\end{array}$ & $\begin{array}{l}\text { Total insured } \\
\text { herd value }\end{array}$ & $\begin{array}{l}\text { Dummy to } \\
\text { purchase } \\
\text { IBLI }\end{array}$ & $\begin{array}{c}\text { Total insured } \\
\text { herd value }\end{array}$ & $\begin{array}{l}\text { Dummy to } \\
\text { purchase } \\
\text { IBLI }\end{array}$ & $\begin{array}{l}\text { Total insured } \\
\text { herd value }\end{array}$ \\
\hline Head completed years of & -0.050 & $-8.440^{* * *}$ & $-0.127^{* *}$ & -1.812 & -0.034 & -8.456 & -0.060 & 3.557 \\
\hline & $(0.033)$ & $(2.588)$ & $(0.063)$ & (1.992) & $(0.039)$ & $(6.198)$ & $(0.070)$ & $(4.942)$ \\
\hline Expected mortality rate & $\begin{array}{c}0.000 \\
(0.002)\end{array}$ & -0.035 & $\begin{array}{l}0.001 \\
(0.003)\end{array}$ & -0.163 & 0.000 & -0.119 & 0.002 & -0.376 \\
\hline $\begin{array}{l}\text { Expected livestock price } \\
\text { (unchange) }(=1)^{\mathrm{a}}\end{array}$ & $\begin{array}{l}0.054 \\
(0.244)\end{array}$ & $\begin{array}{c}13.061 \\
(10.251)\end{array}$ & $\begin{array}{l}0.535^{*} \\
(0.282)\end{array}$ & $\begin{array}{l}(0.10) \\
-0.101 \\
(9.299)\end{array}$ & $\begin{array}{c}0.037 \\
(0.226)\end{array}$ & $\begin{array}{r}64.676 \\
(41.012)\end{array}$ & $\begin{array}{l}0.610^{* * *} \\
(0.279)\end{array}$ & $\begin{array}{l}55.535^{* *} \\
(27.660)\end{array}$ \\
\hline $\begin{array}{l}\text { Expected livestock price } \\
\text { (higher) }(=1)^{\mathrm{a}}\end{array}$ & $\begin{array}{c}0.172 \\
(0.147)\end{array}$ & $\begin{array}{l}-0.692 \\
(8.013)\end{array}$ & $\begin{array}{c}0.072 \\
(0.203)\end{array}$ & $\begin{array}{l}26.916^{*} \\
(14.446)\end{array}$ & $\begin{array}{l}0.094 \\
(0.134)\end{array}$ & $\begin{array}{c}8.417 \\
(32.230)\end{array}$ & $\begin{array}{l}0.245 \\
(0.195)\end{array}$ & $\begin{array}{c}114.608^{* * *} \\
(41.931)\end{array}$ \\
\hline Moderate risk averse $(=1)^{\mathrm{b}}$ & $\begin{array}{c}0.017 \\
(0.193)\end{array}$ & $\begin{array}{c}-21.219^{* *} \\
(9.369)\end{array}$ & $\begin{array}{c}0.131 \\
(0.193)\end{array}$ & $\begin{array}{c}4.827 \\
(11.680)\end{array}$ & $\begin{array}{l}-0.024 \\
(0.172)\end{array}$ & $\begin{array}{r}-83.594^{*} \\
(46.712)\end{array}$ & $\begin{array}{c}0.049 \\
(0.186)\end{array}$ & $\begin{array}{c}1.338 \\
(23.159)\end{array}$ \\
\hline Less risk averse $(=1)^{\mathrm{b}}$ & $\begin{array}{l}-0.022 \\
(0.129)\end{array}$ & $\begin{array}{l}-11.383 \\
(10.104)\end{array}$ & $\begin{array}{c}-0.529^{* * * *} \\
(0.198)\end{array}$ & $\begin{array}{l}-22.773^{*} \\
(13.697)\end{array}$ & $\begin{array}{l}-0.136 \\
(0.135)\end{array}$ & $\begin{array}{l}-68.167 \\
(42.352)\end{array}$ & $\begin{array}{l}-0.579^{* * *} \\
(0.205)\end{array}$ & $\begin{array}{l}-29.756 \\
(24.690)\end{array}$ \\
\hline Constant & $\begin{array}{l}-1.246^{*} \\
(0.731)\end{array}$ & $\begin{array}{l}-48.387 \\
(55.834)\end{array}$ & $\begin{array}{l}-0.460 \\
(0.765)\end{array}$ & $\begin{array}{c}20.801 \\
(120.337)\end{array}$ & $\begin{array}{c}0.293 \\
(0.711)\end{array}$ & $\begin{array}{l}-198.694 \\
(165.018)\end{array}$ & $\begin{array}{l}-2.431^{* *} \\
(1.066)\end{array}$ & $\begin{array}{l}-382.218^{* *} \\
(179.028)\end{array}$ \\
\hline Woreda dummies & Yes & Yes & Yes & Yes & Yes & Yes & Yes & Yes \\
\hline Observations & 474 & 474 & 474 & 474 & 474 & 474 & 474 & 474 \\
\hline
\end{tabular}

Note: Clustered standard errors at the study-site level are in parentheses. ${ }^{* * *} p<0.01,{ }^{* *} p<0.05,{ }^{*} p<0.1$.

${ }^{\text {a }}$ The omitted category is that expected livestock price becomes lower.

${ }^{\mathrm{b}}$ The omitted category is extremely risk averse. 